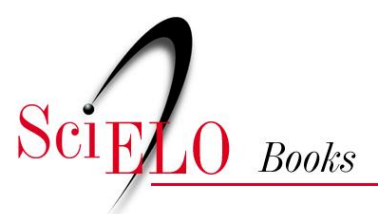

\title{
O som do silêncio da Hepatite C
}

\author{
Francisco Inácio Bastos
}

BASTOS, FI. O som do silêncio da Hepatite $C$ [online]. Rio de Janeiro: Editora FIOCRUZ, 2007. 100

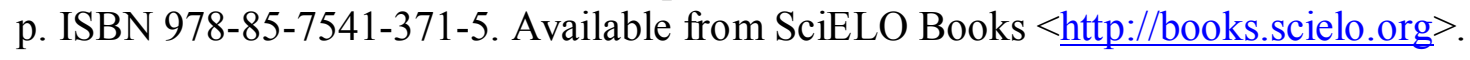

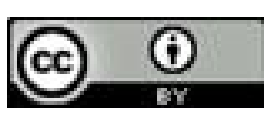

All the contents of this work, except where otherwise noted, is licensed under a Creative Commons Attribution 4.0 International license.

Todo o conteúdo deste trabalho, exceto quando houver ressalva, é publicado sob a licença Creative Commons Atribição $\underline{4.0}$.

Todo el contenido de esta obra, excepto donde se indique lo contrario, está bajo licencia de la licencia Creative Commons $\underline{\text { Reconocimento } 4.0 .}$. 


\section{Som do Silêncio da Hepatite C}

Para minha mãe e minha madrinha, que enfrentaram a adversidade, e resistiram... 


\section{FUNDAÇÃO OSWALDO CRUZ}

Presidente

Paulo Marchiori Buss

Vice-Presidente de Ensino, Informação e Comunicação

Maria do Carmo Leal

\section{EDITORA FIOCRUZ}

Diretora

Maria do Carmo Leal

Editor Executivo

João Carlos Canossa Mendes

Editores Científicos

Nisia Trindade Lima

Ricardo Ventura Santos

Conselho Editorial

Carlos E. A. Coimbra Jr.

Gerson Oliveira Penna

Gilberto Hochman

Ligia Vieira da Silva

Maria Cecilia de Soura Minayo

Maria Eliqabeth Lopes Moreira

Pedro Lagerblad de Oliveira

Ricardo Lourenço de Oliveira

Coleção Temas em Saúde

Editores Responsáveis

Maria do Carmo Leal

Nísia Trindade Lima

Ricardo Ventura Santos 


\section{Som do Silêncio da Hepatite C}

FRANCISCO INÁCIO BASTOS

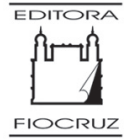


Copyright (C) 2007 do autor

Todos os direitos desta edição reservados à

FUNDAÇÃO OSWALDO CRUZ / EDITORA

ISBN: 978-85-7541-133-9

Capa e projeto gráfico

Carlota Rios

Editoração eletrônica

Ramon Carlos de Moraes

Revisão

Ana Lúcia Prôa

Supervisão Editorial

M. Cecilia G. B. Moreira

Catalogação-na-fonte

Centro de Informação Científica e Tecnológica

Biblioteca da Escola Nacional de Saúde Pública Sergio Arouca

B327s Bastos, Francisco Inácio

O Som do Silêncio da Hepatite C. / Francisco Inácio Bastos. - Rio de Janeiro: Editora FIOCRUZ, 2007.

100 p., il.

1.Hepatite C. 2.Fatores de Risco. 3.Assistência

Médica. 4.Sistema Único de Saúde. I.Título.

CDD - 20.ed. - 616.3623

2007

EDITORA FIOCRUZ

Av. Brasil, 4036 - Térreo - sala 112 - Manguinhos

21040-361 - Rio de Janeiro - RJ

Tels: (21) 3882-9039 / 3882-9041

Telefax: (21) 3882-9006

e-mail: editora@fiocruz.br

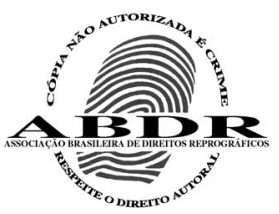

http://www.fiocruz.br 
(...) foram cascas de ar no chão de espelhos.

Carlos Nejar 


\section{SUMÁrio}

Apresentação

1. E a Terra Era Lodo Torvo

2 - Moléculas, Fluidos \& Arquiteturas

3 - Uma Túnica de Várias Cores

4 - Mundo, Mundo, Vasto Mundo

5. Por Mares Nunca Dantes Navegados

Notas Finais: o som do silêncio

Sugestões de Leituras 



\section{Apresentação}

O escritor argentino Ernesto Sábato denominou, com muita felicidade, uma das suas coletâneas de ensaios $O$ Escritor e seus Fantasmas. De fato, tanto escritores de ficção como de não-ficção se vêem às voltas com seus fantasmas, de natureza algo distinta, uns dos outros. Não resta dúvida de que a escrita ficcional, de romances, contos e poesias, está mais próxima dos sentimentos e angústias pessoais dos seus autores do que a maioria dos livros-texto, ensaios acadêmicos e artigos científicos. Constitui um erro, entretanto, atribuir ao conjunto dos textos de não-ficção um caráter frio, exclusivamente objetivo e impessoal. O presente livro não almeja, de forma alguma, esta suposta objetividade cartesiana, mas, ao contrário, contribuir para o debate acerca de uma epidemia contemporânea de grande magnitude e gravidade, a hepatite C, com aportes que julgo fundamentais e pouco explorados pela literatura corrente, de natureza psicológica, social ou histórica. Faço isso, deste modo, não só em decorrência de minha visão do que constitui um ensaio em saúde pública, mas igualmente acossado pelos meus próprios fantasmas, o que menciono a seguir.

Iniciei minha carreira médica como psiquiatra e, ao longo de muitos anos de prática e pesquisa, trabalhei de forma contínua com a população de usuários de drogas (em especial, nas 
suas formas mais graves e danosas, como no caso dos usuários de drogas injetáveis). A despeito de ter investido boa parte dos meus esforços na pesquisa referente à infecção pelo HIV/Aids, tema que perpassa a ampla maioria das minhas pesquisas e trabalhos (inclusive um primeiro volume, similar a este, também incluído na Coleção Temas em Saúde, da Editora Fiocruz), a hepatite $C$ vem me assombrando de forma intermitente, como um fantasma ao qual não tenho dedicado a atenção que gostaria e deveria.

Em anos recentes, muitos dos meus pacientes vivendo com Aids, que atendo semanalmente em uma instituição voltada para a população carente, basicamente residente em comunidades faveladas, nas ruas do entorno da Quinta da Boa Vista e Central do Brasil, no Rio de Janeiro, têm falecido, quando não em virtude da violência, em decorrência da dupla infecção (o que, tecnicamente, denominamos co-infecção) pelos vírus da Aids e da hepatite C. Tinha, portanto, de encarar esse grande vilão da minha prática como médico e pesquisador, que é a co-infecção por esses dois vírus, a reverter, em boa medida, os inequívocos ganhos relativos ao tratamento da Aids.

O fato de acompanhar, quase exclusivamente, uma população que faz uso abusivo de álcool e drogas ilícitas, como a cocaína, com problemas psiquiátricos importantes, como depressão e esquizofrenia, me levou a compreender claramente que não há como lidar de forma adequada com os riscos de contrair a hepatite $C$, assim como com as suas conseqüências entre os cronicamente infectados, se não explorando aspectos não estritamente biomédicos desses pacientes, no seu contexto social e familiar. 
Não se trata, de forma alguma, de uma suposta tentativa de 'desconstruir' o modelo biomédico. Estas tentativas me parecem, o mais das vezes, equivocadas e simplistas, e feitas às expensas de um adequado manejo de regimes terapêuticos complexos, que podem fazer a diferença entre a vida e a morte. Não há, por ora, nada por desconstruir, mas sim por construir, pois pouco existe, em nosso país, em termos de assistência médica de qualidade para pacientes com hepatite $\mathrm{C}$ crônica, no contexto do Sistema Único de Saúde (SUS). Cotidianamente, vejo meus pacientes tentando, por todos os modos, obter, a custo zero (pois se trata de uma população totalmente desprovida de recursos), os sofisticados e extremamente dispendiosos medicamentos de que necessitam. Como mencionei aos editores da Coleção Temas em Saúde, antes mesmo de iniciar a redação deste livro, queria, no meu íntimo, trazer ao público não especializado informações acessíveis sobre o tema (o que espero ter conseguido), mas, antes de tudo, contribuir, dentro das minhas limitações pessoais e profissionais, para melhorar a assistência prestada a esses pacientes. Estes peregrinam, de cá para lá, em busca de medicações capazes de salvar suas vidas, aguardam em filas de espera por consultas, exames e remédios, e, muitas vezes, vêm a adoecer gravemente e falecer, em meio a essa Odisséia rumo ao Eldorado de um tratamento de qualidade.

Os anos vividos não me permitem ser ingênuo a ponto de achar que um pequeno livro vá, de alguma forma, alterar esse estado de coisas, entretanto, não me fizeram cínico e indiferente o bastante para acreditar que devo assistir a esses gravíssimos problemas de braços cruzados. Se de alguma forma os eventuais leitores deste livro ampliarem suas 
informações sobre a questão e, mais do que isso, se conscientizarem de que é preciso melhorar, em muito, a prevenção e a assistência referente às pessoas vivendo com hepatite $\mathrm{C}$ crônica, um dos meus fantasmas mais queridos terá alçado vôo para longe do sótão da minha memória e consciência. 


\section{IE a Terra era Lodo Torvo..}

Quando, na década de 80, cursava medicina, ouvi falar de algo que parecia ser uma doença, ainda que (in)definida a partir de duas negações, a então denominada "hepatite não-A e nãoB". Como todo jovem imbuído de curiosidade cientifica, disse lá para os meus botões (pois à época, ainda se utilizava essa metáfora de alguém em diálogo com seus próprios botões, provavelmente da camisa, pois nas calças já se usavam zíperes): estranha doença esta, que se caracteriza pelo que não é!

Não é possível em ciência, assim como em qualquer ramo da atividade humana, lidar de forma racional com aquilo que desconhecemos e que não podemos nem ao menos nomear, pois a atribuição de um nome, uma designação, traz embutida a inserção do novo objeto ou sujeito na teia de relações que norteiam a ciência e as demais operações racionais. Não são, portanto, inócuas mudanças deliberadas de designação, como, por exemplo, de lepra para hanseníase. Neste último caso, a designação original, lepra, se revestiu de tamanha carga de estigmatização, quando não da exclusão e ostracismo do então denominado leproso da vida em comunidade (como fartamente documentado desde os tempos bíblicos), que passou a veicular antes um conjunto de preconceitos do que uma designação útil para a prática clínica e uma designação socialmente aceitável.

Seguindo com tópicos explorados pela Bíblia, constatamos que o Gênesis, o livro primeiro da Bíblia, expressa a idéia de que 
a designação constitui parte essencial e estrutura as coisas do mundo: "E Deus chamou à luz dia / e à treva chamou noite / E foi tarde e foi manhã / dia um" (Gen 1,5). (Estes versículos bem como o que dá o título ao capítulo 1 - Gen 1,2 - constam da tradução de Haroldo de Campos).

Ou seja, é a partir da nomeação precisa de cada elemento do mundo que o mundo como tal se inaugura: o dia um (primeiro).

O que fazer, então, com uma doença que se define tão-somente por uma dupla negação? Bom, sabe-se que se trata de uma hepatite, ou seja, de uma doença que afeta o fígado; mas o que seria algo que não é A nem B? Trata-se de uma hepatite que difere das hepatites até então identificadas, a hepatite A, de longe, a mais freqüente e longamente conhecida, e a hepatite $B$, que havia sido identificada de forma clara na década de 60 . Na década de 40 (mais precisamente, em 1947), o médico inglês MacCallum publicou um artigo em que distinguia a hepatite $A$, decorrente da contaminação de alimentos e da água, da hepatite B, transmissível pelo sangue.

Mas a comprovação definitiva da existência da hepatite B e da presença do seu agente causador (um vírus) no sangue teria de esperar o ano de 1963, quando dois pesquisadores norteamericanos, Baruch Blumberg e Harvey Alter, identificaram no sangue de um paciente australiano (um aborígine, ou seja, um membro da população nativa da Austrália) um elemento do vírus da hepatite $B$, que denominaram antígeno Austrália. Poderse-ia pensar em alguma implicância para com os australianos, mas, na verdade, deve-se à eterna necessidade de atualizar e padronizar a terminologia científica a substituição do sonoro antígeno Austrália pela insípida sigla HBsAg (acrônimo para antígeno $S$ ou de superfície da hepatite B; entendendo-se aqui a palavra 
superfície como equivalente à porção mais externa do vírus ou, em termos mais precisos, seu 'envelope'). Blumberg receberia, em 1976, o Prêmio Nobel por sua descoberta, e o então jovem pesquisador Harvey Alter (agraciado, em 2000, com outra distinção não tão conhecida como o Prêmio Nobel, a comenda Albert Lasker) participaria decisivamente da descoberta da hepatite $C$, o que veremos a seguir.

O caráter ao mesmo tempo disseminado (a metáfora do "chão de espelhos") e vago ("cascas de ar") da então hepatite não-A e não-B, ilustrado na epígrafe do poeta Carlos Nejar, fez com que não fosse possível instituir medidas específicas visando à sua prevenção - afinal, não se previne algo que não se conhece, e não se conhece algo que não se pode nem ao menos designar. A disseminação silenciosa e invisível da hepatite, que, a partir de 1989, seria designada como hepatite $C$ se revelou mais tarde um problema crucial de saúde pública em todo o mundo e constitui o tema deste livro.

\section{A hepatite $C$ emerge}

Em 1989, a partir de soros de pacientes infectados pela hepatite não-A e não-B, o pesquisador norte-americano Michael Houghton, em parceria com Choo, Kuo e o supra-citado Alter, isolaram um novo vírus, que caracterizam como sendo o agente etiológico (causal) de uma 'nova' hepatite, a hepatite C. Cabe observar aqui que esse abecedário das hepatites virais representa tão-somente o início da frutífera incursão da ciência pelo universo das hepatites virais. Com o tempo, outras letras, como D e E, e por aí vai, foram acrescentadas ao repertório das hepatites virais. 
Transcorrido um ano do isolamento do vírus da hepatite $\mathrm{C}$ (VHC no acrônimo em português ou HCV em língua inglesa), inicia-se a testagem visando ao rastreamento de amostras de sangue a serem processados (para fabricação de componentes denominados hemoderivados) ou diretamente transfundidas para pacientes necessitados de sangue total ou de componentes específicos do sangue, como no caso dos pacientes hemofílicos. Estes pacientes habitualmente precisam receber componentes que integram a cadeia da coagulação sangüínea, que seu organismo não consegue produzir por si só. A partir da identificação da hepatite $\mathrm{C}$ e do desenvolvimento de testes específicos, os estoques de sangue passam a ser rastreados para mais um agente infeccioso, desta feita, o VHC. Cabe lembrar que, quase à mesma época, tem lugar intensa mobilização social e política em torno da outra epidemia que emerge em todo o mundo (o que tratei em outro livro desta coleção da Editora da Fiocruz: Aids na Terceira Década) - a epidemia de Aids.

As duas epidemias seguiram trajetórias absolutamente contrastantes, a despeito da grande magnitude, disseminação mundial e gravidade, em termos de saúde publica de ambas. Apesar de afetar hoje, em todo o mundo, algo como 150-200 milhões de pessoas, entre infectados pelo VHC e doentes afetados pela hepatite $C$ na sua expressão clínica (o que detalharei), a hepatite C evoluiu como uma epidemia praticamente invisível, por razões não de todo conhecidas, mas que discutirei a seguir.

\section{Aids $x$ hepatite $C$}

Ambas, hepatite $\mathrm{C}$ e Aids, resultam de infecções por vírus que progridem para doenças/síndromes de forma relativamente lenta, o já mencionado VHC e o vírus da imunodeficiência 
humana (VIH ou HIV, este último acrônimo cunhado a partir da denominação inglesa), respectivamente. Por atacar diretamente as células da imunidade, o VIH/HIV determina uma progressão para a síndrome clínica (Aids) relativamente mais rápida do que o VHC, progressão esta, até o presente momento, inevitável, uma vez instalada a infecção. Já no caso do VHC, a progressão para doença grave (fibrose e, eventualmente, cirrose e câncer hepático; como veremos em detalhe mais adiante) é, não apenas, mais lenta (podendo chegar a mais de duas décadas, na ausência de qualquer intervenção médica), mas está restrita a um porcentual relativamente diminuto $(20 \%)$ dos casos de hepatite aguda pelo VHC.

Com isso, nem sempre é possível para os pacientes (e seus familiares) estabelecer um nexo causal entre uma infecção pouco relevante (ao menos, subjetivamente), ocorrida há mais de vinte anos atrás, e os sintomas que ora experimentam. Nos indivíduos que se mantêm por longos anos livres de quaisquer sintomas, o achado da infecção pelo VHC é muitas vezes casual, em função, por exemplo, de um exame de sangue de rotina. Para diversos pacientes com quem conversei ao longo da minha trajetória como médico e pesquisador, e que não referiam fatores de risco evidentes, como ter recebido transfusões de sangue ou feito uso compartilhado de drogas injetáveis, não era possível estabelecer qualquer conexão entre a presente infecção (detectada por exames de rotina) ou doença e qualquer evento específico das suas vidas. Com isso, o próprio conceito de exposição a um risco específico se perde.

Ao contrário da epidemia da Aids, cuja compreensão se pautou inicialmente pelo conceito (que se mostrou, posteriormente, equivocado) de "grupos de risco", a hepatite C se disseminou em 
todo o mundo sem que ficassem inteiramente claros os fatores específicos de risco de fato associados à infecção em muitos dos casos. Alguns destes fatores se tornaram mais claros recentemente, como, por exemplo, o uso compartilhado de recipientes e líquidos utilizados na auto-administração de drogas injetáveis (na ausência do compartilhamento propriamente dito de agulhas e seringas).

Cabe observar que a conceituação "grupos de risco" é estigmatizante e tecnicamente equivocada em ambos os casos, pois não é o pertencimento, a priori, a uma dada população ou grupo que faz com que um determinado indivíduo esteja sujeito a riscos associados a esta ou aquela infecção. A título de exemplo, uma pessoa que faz uso de drogas injetáveis sem compartilhar quaisquer produtos (como a solução que contém a droga a ser injetada, como a cocaína ou heroína) ou equipamentos (como, por exemplo, agulhas, seringas ou recipientes utilizados na diluição das drogas) não corre risco, do ponto de vista da transmissão sangüínea, de se infectar com vírus como o da hepatite c e da Aids. Estes vírus não são capazes de persistir em ambiente aberto por mais do que alguns minutos (ainda que possam permanecer por tempo bastante mais longo em reentrâncias ou coágulos de sangue) Por outro lado, pessoas que não são vistas (por si próprias ou pelas demais) como usuários de drogas injetáveis, como os atletas que fazem uso de esteróides anabolizantes (conhecidos na gíria como "bombas") para ganhar massa muscular, podem, ao compartilhar equipamentos de injeção com colegas de academia, se infectar com os vírus das hepatites virais ou o vírus da Aids.

Persistem até hoje dúvidas sobre os riscos especificamente associados a outros comportamentos com relação à infecção 
pelo vírus da hepatite $\mathrm{C}$, como o uso em comum de canudos para aspirar a cocaína em pó ou de lâminas de barbear. Com relação a uma proporção substancial de casos, não é possível estabelecer quaisquer fatores de risco específicos, mesmo após investigações exaustivas.

Também diferentemente da Aids, a relevância da transmissão sexual do VHC é bastante reduzida, e, até o momento, cercada de polêmica e contradição. Alguns estudos conduzidos de forma metodologicamente adequada e analisados de forma criteriosa não encontraram evidências de que o VHC seja de fato transmitido sexualmente. Outros estudos encontraram, ao contrário, evidências da transmissão sexual do vírus da hepatite $C$, ainda que com uma força de infecção (infectividade) bastante limitada, sob o ponto de vista da transmissão sexual, se comparada, por exemplo, à infectividade do vírus da hepatite B. Seja lá como for, a hepatite $\mathrm{C}$ não é classificada na literatura médica atualmente como uma infecção/doença sexualmente transmissível.

Se nem os especialistas conseguem se entender, o que dizer das demais pessoas que não têm acesso a achados de pesquisa de forma regular? Embora alguns trabalhos recentes apontem para uma vulnerabilidade ampliada de determinadas minorias sexuais, como os homossexuais masculinos, frente à infecção pelo VHC, não existiu ou existe qualquer mobilização de massa ou comunitária com relação a isso. As comunidades gays, especialmente dos países desenvolvidos, cuja mobilização foi central aos esforços de prevenção da epidemia de Aids desde o início da década de 80, não se mobilizaram em escala minimamente comparável em torno da hepatite C. Esta constatação não se deve revestir, entretanto, de nenhuma forma de crítica. Às voltas com uma epidemia emergente (a Aids), com elevadíssima mortalidade à época 
(quando não existiam quaisquer alternativas terapêuticas), de feições então quase (totalmente) misteriosas e que afetava de forma inequívoca sua comunidade, não haveria como pedir aos ativistas que se mobilizassem em torno de uma segunda ameaça que não se podia precisar naquele tempo. Ameaça esta em relação à qual os especialistas não chegavam (e não chegam) a um consenso com relação a uma possível vulnerabilidade ampliada de populações específicas recortadas segundo suas práticas sexuais.

Transmissão sexual à parte, restavam, sob o fogo cruzado de mais uma infecção, os usuários de drogas injetáveis. Não que eles não tenham se mobilizado em torno das hepatites virais (à época " início da década de 80 " as hepatites B e C, não claramente individualizadas, tanto pelos profissionais de saúde como pelos próprios usuários de drogas). Muito ao contrário, se mobilizaram sim, tendo estabelecido por conta própria o primeiro programa de troca de seringas (usadas, potencialmente contaminadas, por novas, estéreis), em Amsterdã, Holanda, já em 1984, como detalhado em livro mencionado anteriormente (Aids na Terceira Década).

Mas são notórias as dificuldades de mobilização dos usuários de drogas, a começar pela sua marginalização, criminalização, na maior parte das sociedades em todo o mundo, passando pelas dificuldades inerentes ao próprio consumo abusivo de drogas e pela ausência de canais formais de comunicação e representação na sociedade. Além disso, como diz o ditado: uma andorinha só não faz verão.

Após ter redigido as linhas anteriores, descobri casualmente um artigo na base de dados Medline (da Biblioteca Nacional de Medicina, dos EUA), que desenvolve raciocínio similar. Os seus autores, os pesquisadores australianos Korner e Treloar analisam 
os editoriais das principais revistas médicas, concluindo que, no que diz respeito ao HIV/Aids, estão presentes as dimensões sociais, culturais, e a voz dos indivíduos diretamente afetados pela epidemia, com destaque para a mobilização das comunidades gays dos países desenvolvidos; em contrapartida, a hepatite C é uma questão vista quase exclusivamente a partir da óptica da pesquisa biomédica e da prática médica. Como assinalam os autores, a perspectiva estreita com que é encarada a hepatite $C$ exclui a participação direta das pessoas por ela atingidas e desencoraja a mobilização da sociedade.

A epidemia de hepatite $C$ teria de esperar por muitos anos de silêncio até que se constituíssem grupos de ajuda mútua e ativismo com passagem efetiva pela sociedade mais abrangente. Existir, sem dúvida, tais grupos existem, desempenhando um papel extremamente relevante no combate à epidemia e auxílio aos pacientes e seus familiares. Mas, ao menos sob a minha perspectiva, tem sido bastante difícil para estes grupos abrir um espaço específico para a hepatite $C$ em uma agenda global saturada pelos mais diferentes problemas, que abrangem desde doenças tradicionais para as quais não se encontrou ainda resposta de fato global (como a Aids, a tuberculose e a malária), passando por problemas decorrentes da degradação do meio ambiente, como o aquecimento global, a escassez de água potável e a extinção de diversas espécies de plantas e animais, compreendendo ainda a fome e as guerras e conflitos nas mais diferentes latitudes.

O eventual leitor deste texto já deve estar se sentindo cansado de tantos males e problemas, e pronto para fechar o livro. Antes disso, porém, terminemos o capítulo, anunciando a etapa subseqüente: um pouco de biologia, para não especialistas, a começar pelo próprio autor, que não é biólogo. 


\section{I Moléculas, Fluidos \& Arquiteturas}

Neste capítulo, pretendo esclarecer alguns dos aspectos mais bem conhecidos da fisiopatologia da hepatite C crônica, ou seja, como, de forma simplificada, transcorre o processo que vai da invasão do organismo (com destaque para fígado) por parte de um bem disposto exército de vírus até a geração de lesões no fígado e reações das estruturas de defesa contra o próprio organismo (a auto-imunidade). Ao longo desse processo, a arquitetura original do fígado vai sendo distorcida e perdendo sua capacidade de funcionar em sintonia com o resto do organismo. Ou seja, a estrutura e o funcionamento do fígado e outros órgãos se afastam, progressivamente, do funcionamento fisiológico (habitual) e percorrem os caminhos dos processos fisiopatológicos, aqueles que alimentam a dinâmica que gera as patologias desta ou daquela molécula, deste ou daquele órgão, deste ou daquele sistema. As patologias, com freqüência, mas não necessariamente, se expressam sob a forma de doenças, com seus sinais e sintomas.

No caso específico da infecção pelo VHC, o processo ocorre, de um modo geral, de forma bastante lenta e descontínua (ao menos do ponto de vista do próprio paciente e de seu médico), ainda que na intimidade das moléculas e tecidos as coisas não se passem exatamente assim, mas, de fato, através da acumulação progressiva de mudanças sutis e imperceptíveis, na tênue linha divisória entre a fisiologia e a fisiopatologia (ou seja, 
entre o funcionamento dito normal de um dado órgão ou sistema " fisiologia " e o seu funcionamento patológico ou fisiopatologia).

Seja como for, por razões ainda não inteiramente claras, algumas pessoas são capazes de eliminar espontaneamente os vírus da hepatite $C$ quando da vigência da infecção aguda, enquanto a maioria delas evolui com uma infecção crônica, ao longo de décadas, sem manifestar problemas mais graves. Finalmente, uma minoria evolui com quadros de lesão extensa do fígado e problemas importantes, secundários à agressão viral e à ação dos mecanismos de auto-imunidade, o que pode se revestir de gravidade clínica, em quadros como a cirrose hepática (o que é discutido, sob diferentes prismas, nos capítulos subseqüentes deste livro).

Portanto, os fenômenos que abordarei a seguir não devem ser vistos como um caminho único e inevitável seguido pela infecção pelo vírus da hepatite $\mathrm{C}$ em qualquer organismo, mas sim como caminhos que, a cada etapa, se bifurcam, gerando histórias distintas da evolução da infecção nos diferentes seres humanos.

Possivelmente devido ao apelo visual e intuitivo que diagramas com bifurcações trazem à representação de possibilidades pela mente humana, e quem sabe numa homenagem implícita ao conto do escritor argentino Jorge Luis Borges ("O jardim dos caminhos que se bifurcam”), em que cada bifurcação gera histórias alternativas, de um conjunto (infinito?) de histórias possíveis, os mais diferentes artigos e sites que consultei em busca de informação atualizada para escrever este livro, mostram sempre os mesmos diagramas com sucessivas bifurcações para representar a evolução da infecção pelo VHC ao longo do tempo. 
Estas sucessivas bifurcações fazem com que, na hepatite C, de forma mais acentuada que em diversas outras doenças, de evolução mais rápida e linear, cada caso seja, muito precisamente, um caso específico. Isto não apenas no sentido psicossocial de que cada ser humano é um indivíduo singular, mas no sentido dos fenômenos sutis que ocorrem ao nível do chamado "mundo médio" (termo a que fui apresentado recentemente pelo trabalho do físico inglês Mark Haw) das interações biológicas, como o fluxo sangüíneo e os tecidos que compõem nossos órgãos, e nas diferentes subdimensões do mundo microscópico, envolvendo átomos, moléculas, substâncias e células.

É também neste sentido que os indivíduos são, simultaneamente, um organismo estruturado com características únicas e um conjunto de tudo menos unidades indivisíveis, como mostra, paradoxalmente, a etimologia da palavra: indivíduo $=$ indiviso (aquele/aquilo que não é passível de divisão). Deste último ponto de vista, somos, na verdade, a resultante dinâmica, e nada unitária ou coerente, de uma permanente rede/ fluxo de milhões de interações de componentes de diferentes complexidades e tamanhos, desde os átomos e seus componentes subatômicos a estruturas relativamente maiores e mais complexas, como órgãos (como o fígado) e sistemas (como o sistema digestivo). Talvez para que não venhamos a enlouquecer de vez, acabamos por esquecer essas dinâmicas e fluxos, em prol de um eu, unificador, supostamente estável. Da biologia molecular ao budismo, tal unicidade e suposta coerência é vista como uma construção desprovida de qualquer plausibilidade, mas será que conseguiríamos compreender a nós mesmos tão-somente como uma combinação móvel de interações e contingências? 
O leitor deve estar se perguntando: ora, se todos nós somos compostos pelas mesmas moléculas, substâncias, ou, em um nível mais elementar, se a água e o oxigênio que compõem meu corpo são idênticos aos que compõem o corpo do meu vizinho, como e por que somos diferentes? O que faz de mim eu mesmo (ainda que com as ressalvas vistas anteriormente)? E o que faz do outro, ele mesmo (considerando-se também as mesmas ressalvas)?

A resposta é simples e complexa. Complexa, se quisermos mergulhar nas infinitas inter-relações entre cada um desses componentes, mas simples, se adotarmos a bela metáfora do físico norte-americano Richard Feynman, em um dos seus textos mais inspirados e poéticos, denominado: O Valor da Ciência, de 1955. Nele, Feynman nos diz que, a cada dia, nosso corpo incorpora e elimina milhões de elementos, invariavelmente iguais entre si, como os átomos de carbono ou hidrogênio. Com certeza, o elétron do oxigênio que permaneceu em mim por alguns instantes, talvez, quem sabe, minutos, em nada difere do elétron que está naquele momento se movimentando (sabe-se lá por que caminhos; mas esta já é uma outra história) nos átomos de oxigênio dos outros bilhões de meus confrades humanos. Então, por que cada um é supostamente um, se nada que o compõe permanece?

Feynman recorre ao conceito de padrões e estruturas, mas o faz de uma forma inusitada, comparando-os à dança. Ou seja, cada elétron segue seu curso, indiferente a estar, por ora, neste ou naquele outro organismo. Mas quando vários átomos se juntam para compor moléculas, células, tecidos, e assim, sucessivamente, isso ocorre segundo padrões definidos (ainda que bastante dinâmicos) de inter-relação e interação, como num 
repertório de danças que só aquele conjunto de bailarinos sabe e pode dançar daquela maneira. Uma forma única de dançar, com bailarinos que entram e saem, apressados, a cada instante, mas que, enquanto vivermos, e contarmos com uma companhia de dança que não deixa de encenar os balés que nem teve tempo de ensaiar, persiste, sempre com inúmeras variações (pois daí derivam nossa flexibilidade e adaptabilidade). Esta dança, diz Feynman, somos nós.

Fica fácil entender assim, penso eu (se, de fato, existo enquanto tal!) o porquê de evoluções tão singulares da hepatite $C$ nos diferentes indivíduos. É que tudo resulta das piruetas dos invasores que irrompem no palco, exigindo participar da apresentação, os vírus, e de como o corpo de baile reage a esses visitantes inesperados. Ficamos sempre entre o desejo de expulsá-los a pontapés e de convidá-los a dançar... E como será que eles entram em cena?

Assim que os vírus entram no organismo, nossa primeira reação é expulsá-los a pontapés e bofetões, bofetões e pontapés imunológicos, cabe esclarecer. O organismo se lança ao ataque, secretando substâncias antivirais, denominadas interferons (neste caso, interferons alfa e beta; maiores detalhes acerca dos interferons estão disponíveis nos capítulos subseqüentes). Os interferons, por seu turno, induzem tanto a produção de outras substâncias com ação direta sobre os vírus (matando-os ou tentando matá-los), como as enzimas proteíno-quinases, como induzem células fagocíticas (que fagocitam, ou seja, engolem os vírus) e assassinos naturais, cujo nome não faria feio nos créditos de um filme de James Bond, como os linfócitos denominados NK (natural killers), algo parecido com matadores de aluguel, a serviço do nosso organismo, felizmente. 
Por seu turno, esses 'assassinos naturais' secretam quantidades adicionais de interferon, mobilizando, progressivamente, à medida que mais e mais invasores estão chegando e se multiplicando, nossas defesas, ampliando e aprofundando a resposta imune aos vírus. Em algumas horas, ambos os exércitos estão alinhados, limpando suas armas para as próximas refregas, que passam a envolver diferentes células assassinas, anticorpos (que buscam identificar e, se possível, destruir os vírus invasores, a partir do reconhecimento de parte das suas estruturas, os antígenos) e vírus, muitos vírus, milhões e milhões deles. O organismo aposta na variedade e complementaridade das suas ações; os vírus, por sua vez, apostam antes na sua capacidade desconcertante de se transformarem e adaptarem. O combate lembra as batalhas entre exércitos regulares (organismo) e guerrilheiros (vírus), e os últimos acontecimentos do nosso, digamos, macromundo (o mundo das nações, neste caso específico, em guerra) mostram que não é nada fácil (se não, impossível) derrotar definitivamente guerrilheiros, mediante a utilização de forças militares regulares.

Nada de muito diferente ocorre nos nossos organismos, pois, apesar da formidável mobilização das nossas defesas, os vírus, literalmente, 'pintam e bordam'. E não é que pintam e bordam tanto e tanto, que acabam por confundir nossas defesas, que, no esforço de combatê-los, acabam por se voltar contra o próprio organismo, no fenômeno denominado auto-imunidade, ou, voltando às metáforas bélicas (terrivelmente sarcásticas) de um mundo (o nosso) permanentemente em guerra, me vem à mente a expressão "fogo amigo", ou seja, o que ocorre quando um soldado dispara contra a sua própria tropa. Assim, como ocorre no macro mundo, o fogo amigo, também no micro mundo, fez e faz inúmeras vítimas. 
Os vírus são 'ardilosos' e 'ariscos' como o quê, e não apenas mudam e se transformam em novos elementos, indetectáveis aos 'olhos' imunológicos do organismo, como também sabotam as defesas do adversário, 'metendo o bedelho', por exemplo, na síntese de substâncias que objetivam exatamente combatê-los. Sabe-se hoje, por exemplo, que os vírus são capazes de atrapalhar (e mesmo impedir) a síntese do próprio interferon. Não é à toa, portanto, que o interferon tenha se transformado em uma medicação (não sendo mais, portanto, apenas um produto biológico natural, produzido pelo próprio organismo), administrada aos pacientes infectados pelo VHC e outros vírus. Pois, se no interior do organismo, a produção de interferon é constantemente sabotada pelos próprios vírus que ele busca combater, há que se recorrer ao suprimento externo.

Não resta dúvida de que nossos criminosos (os do macro mundo brasileiro) são engenhosos, como nos assaltos que vêm realizados na minha pobre cidade natal, o Rio de Janeiro, usando roupas, armamentos e, mais recentemente, viaturas, em tudo similares às das próprias forças de segurança. Fala-se mesmo em "clonagem" de uniformes e viaturas, como destacou a manchete de um jornal popular. Pois se os criminosos se dessem ao trabalho de estudar um pouco de virologia e biologia molecular (o que certamente não farão), aprenderiam que o comportamento dos vírus antecede, em centenas de milhares de anos, suas mais recentes criações. Pois os vírus são capazes de imitar, à perfeição, diferentes estruturas essenciais tanto à preservação do organismo, como às ações que buscam combatê-los. O organismo, tonto com o engenho e a arte de seus invasores, começa por bater a torto e a direito, agredindo o que vê pela frente. Como se podia prever, 
perdida a inteligência do combate e apelando-se, cegamente, à força bruta, os resultados costumam ser desastrosos, o que veremos a seguir.

\section{ORGANISMO CONTRA-ATACA ... A A SI MESMO}

Tonto como um boxeador nas cordas, cansado de bater e de apanhar, o organismo (exceção feita aos indivíduos que conseguem eliminar os vírus após um episódio de infecção aguda, vide capítulos subseqüentes), passa a desempenhar um papel semelhante aos famosos agentes duplos que teriam povoado o mundo no período denominado Guerra Fria (entre o término da Segunda Guerra Mundial e o colapso dos regimes comunistas no Leste europeu e na União Soviética, ao final da década de 80), e que continuam a animar as películas de James Bond e congêneres (que o leitor perdoe o retorno a esta pobre metáfora, mas é que sou fã do gênero). As forças do organismo atuam, portanto, de forma imbricada, sendo difícil, se não impossível, destrinchar suas ações individuais, tanto no combate aos vírus como na geração de lesões teciduais, progressivamente mais extensas e mais graves, não apenas no fígado, como em diversos outros sistemas do organismo (ver detalhes no capítulo 3). Ou seja, os elementos do próprio organismo agem tanto a favor como contra o organismo que supostamente protegeriam.

A auto-imunidade é um fenômeno complexo, presente em diversas doenças, vinculadas ou não (até onde a ciência contemporânea sabe informar) a agentes infecciosos. Haveria, a princípio, algo como um gatilho, um mecanismo que faria com que as células e compostos orgânicos que, até então, protegiam o organismo de seus eventuais agressores, passem a atacar o próprio organismo, que passam a reconhecer, ao menos em parte, como 
algo distinto do 'eu imunológico' (ou seja, a identidade de cada um de nós da perspectiva do nosso sistema imunológico).

$\mathrm{Na}$ verdade, como sempre, a realidade é bastante mais complexa e intrincada do que quaisquer raciocínios esquemáticos, e não existe aqui uma radical separação entre eu e não-eu (imunológico). Vamos recorrer brevemente a uma das maiores autoridades mundiais em imunologia das doenças auto-imunes, o norteamericano, naturalizado israelense, Irun Cohen. Vejamos o que ele tem a nos dizer.

Cohen, que, além de cientista, é um refinado filósofo e literato, começa sua análise heterodoxa pela etimologia da palavra imunidade. Fosse ele brasileiro, e não israelense-americano muito provavelmente acrescentaria, com prazer, novas metáforas às suas, já tão saborosas. É que, diz ele, imunidade provém do latim immunitas, ou seja, isenção, diante de, por exemplo, impostos ou outras taxações e pagamentos (algo que estava reservado a certas frações da sociedade romana). Imediatamente, me veio à mente, como bom brasileiro, o instrumento jurídico que confere imunidade aos nossos representantes legais, a mal-afamada imunidade parlamentar. Bom, diz Cohen, já a partir da própria denominação, exige-se da imunidade algo que ela não pode oferecer, pois o organismo não está acima do bem e do mal (como, supõe-se, estariam nossos parlamentares ou os antigos nobres romanos), isento de quaisquer custos (taxações) impostos pelo meio ambiente, predadores e parasitas, e tem de se haver com as agruras diárias, despendendo, para tal, energia e lançando mão da informação e da vigilância permanente.

Com isso, a visão de um sistema imunológico semelhante a um interruptor de tomada, que liga e desliga, se mostra totalmente inadequada. $\mathrm{O}$ sistema imunológico trabalha de forma 
contínua, e antes tolera do que ataca, na imensa maioria das ocasiões. Basta pensar nas nossas refeições diárias, nos remédios que eventualmente tomamos, nos produtos químicos com que interagimos cotidianamente, queiramos ou não. Pensemos ainda no sofrimento dos alérgicos, que reagem de forma intensa a, digamos, o pólen das plantas, o pêlo dos cães e os ácaros (minúsculos carrapatos, para simplificar). Talvez para surpresa do leitor obcecado com limpeza e higiene, dormimos na boa companhia de milhares de ácaros, todas as noites, por mais que lavemos nossos lençóis. Eles vieram para ficar, e retornam triunfantes à roupa de cama recém-lavada, assim que a trocamos. A não ser para os alérgicos, cabe conviver com eles e quem sabe, em caso de insônia, contar ácaros, em vez dos famosos carneirinhos, que além de tudo são também alergênicos, com suas grossas coberturas de lã.

Portanto, se o sistema imunológico tivesse de escolher com qual das palavras ficaria no famoso título de Tolstoi, Guerra e Paz, ficaria com a Paz, sem pensar duas vezes. Na metáfora de Cohen, a atividade cotidiana do sistema imunológico é antes de manutenção e faxina do que de ataque e defesa. Há muito que limpar, reparar e ajudar a construir no organismo, como nos apartamentos velhos, onde sempre há uma bica pingando, um fio desencapado. À medida que envelhecemos " nós mesmos ", e não apenas nossos apartamentos, há cada vez mais canos entupidos, fiação solta, paredes por pintar no nosso próprio organismo. Penso que exigiríamos demais de nossos sistemas imunológicos, já tão fatigados de reparar e consertar nossos alquebrados organismos, se deles desejássemos que se comportassem como guerreiros ágeis e vigorosos, como o mítico Aquiles, da Guerra de Tróia, e sua ira. Ao ficarmos mais velhos, estamos 
mais para uma equipe de diligentes, mas fatigados, faxineiros do que para intrépidos guerreiros.

Com relação à auto-imunidade, há que distingui-la, inicialmente, da alergia, pois na alergia a eventual agressão ao próprio organismo é uma espécie de subproduto, indesejável, do ataque (exagerado e mal guiado) que movemos contra, por exemplo, um punhado de ácaros ou um bracelete de flores (na verdade, não contra esses animais e plantas em si, mas contra alguns de seus componentes). A auto-imunidade, ao contrário, tem como alvo primário algo que pertence ao nosso organismo, mas que não reconhecemos enquanto tal, a partir da influência de algum gatilho (como os famosos vírus, que a toda hora menciono), ou em função de um processo intrínseco ao nosso próprio organismo, e que altera sua estrutura.

A relação entre auto-imunidade e doenças infecciosas também não tem nada de linear ou simples. Tudo que descrevi até então com relação à hepatite $\mathrm{C}$ e à reação do organismo a esta infecção se prende à dinâmica de uma única infecção, fenômeno que não existe de forma isolada no mundo real. Diariamente, interagimos com centenas de diferentes microorganismos e milhares deles habitam tranqüilamente algumas das nossas regiões de interação com o mundo, como a cavidade bucal e os intestinos (nestes últimos, estima-se que exista mais de $1 \mathrm{~kg}$ de microorganismos). Tais microorganismos, habitualmente, não nos incomodam, assim como não os incomodamos, e nos auxiliam em tarefas imprescindíveis, como digerir alguns alimentos.

Portanto, o sistema imunológico está em interação permanente com inúmeros microorganismos, sem que exista guerra de espécie alguma. Se, por um lado, o vírus da hepatite $C$ pode desencadear uma guerra de amplas proporções, que tem como 
efeitos colaterais o ataque que passamos a mover contra nós mesmos; por outro, há que observar que algumas doenças com componentes auto-imunes, como o diabetes, parecem antes ser parcialmente evitadas por interações bem-sucedidas com agentes infecciosos. Ou seja, neste caso, um histórico de infecções ao longo da infância e juventude protegeria o indivíduo de desenvolver diabetes em um momento posterior da sua vida. Por razões éticas e técnicas tais experimentos não são exeqüíveis em humanos, contudo, em roedores, observa-se que a manutenção de camundongos com imunidade normal em ambientes artificiais, estéreis, sem contato algum com quaisquer germes, faz com que os camundongos apresentem taxas elevadas de diabetes, substancialmente mais elevadas do que seus pares (camundongos em tudo similares aos primeiros), criados em ambientes normais. De alguma forma, as interações com os diferentes agentes infecciosos preparariam o organismo para os embates futuros da vida, entre eles, o desenvolvimento do diabetes.

Trata-se, portanto, de uma faca de dois gumes, ou antes, de uma faca de múltiplos gumes, a desafiar nossa capacidade de compreensão e de como informar de forma racional e apropriada nossas decisões terapêuticas. Até que ponto conviver com este ou aquele microorganismo, indivíduo ou nação? Até que ponto entrar em conflito: aí está o desafio central da diplomacia mundial, e, por que não, da biomedicina das doenças infecciosas, neste conturbado século XXI.

\section{Crime e castigo}

Creio que Dostoievski, um dos autores que descreveu com maior eloqüência os mais profundos tormentos e dilemas da alma humana, não gostaria, a princípio, que o título de um dos 
seus livros fosse utilizado para falar da fibrose hepática. Mas espero convencer o leitor e o fantasma do mestre russo de que minha escolha não é de todo injustificada. Com isso, abandonamos, por ora, o pacato Irun Cohen e nossos abnegados faxineiros, e voltamos às metáforas, se não bélicas, criminais, ou seja, nos afastamos aqui novamente da tão almejada paz.

Como disse anteriormente, os vírus (além das nossas transtornadas células de defesa, estas últimas no esforço, vão, de combater os próprios vírus) movem, quando da infecção crônica pelo vírus da hepatite $\mathrm{C}$, um ataque contínuo contra tecidos do próprio organismo, especialmente contra o tecido hepático. Um jurista - penso eu -, não hesitaria em tipificar (uma das muitas expressões dos juristas) este crime, que une um invasor àqueles que deveriam servir como agentes de defesa contra a referida invasão, como 'associação para a prática de crime', ou mesmo, dado o número e a diversidade de células e vírus envolvidos na ação, atribuiria a este conluio criminoso o propósito de 'formação de quadrilha ou bando armado'.

Anos e anos transcorridos, sob fogo cerrado, e encontramos o pobre fígado fragilizado. O fígado se defende como pode, contra-atacando, com as forças que lhe restam, os agressores (vírus e elementos do próprio organismo), substituindo tecido são e funcional por tecido de reparação, como nesses consertos malfeitos, em que as placas de metal de um carro batido são remendadas de forma apressada e insuficiente com massas plásticas, cobertas por tinta. Se existe castigo para o bando armado representado por vírus e agentes de defesa corrompidos, ele incide, antes de tudo, sobre a própria vítima, mais aos moldes das histórias em quadrinhos de Sin City ("Cidade do Pecado") tiras de quadrinhos de policial noir, criadas pelo desenhista norte- 
americano Frank Miller - do que do próprio Dostoievski, autor a quem move a idéia de uma dramática vingança contra o autor do crime.

Castigo para os invasores $\%$ cabe aqui lembrar $\%$, pode significar castigo para elementos do próprio organismo que, por ora, estão agindo de forma lesiva, em conluio criminoso com os vírus. Portanto, apenas com a moderna terapia tornou-se possível, de fato, interromper o ciclo de destruição e regeneração desordenada, e restaurar a saúde do organismo. Ou seja, retomando as nossas metáforas, estamos, hoje, com as modernas terapias, a caminho de abandonar a "Cidade do Pecado", onde quem paga exclusivamente pelos crimes são as próprias vítimas, em direção a um mundo igualmente passional, mas onde o castigo atinge, antes de tudo, aqueles que perpetram o crime.

Ao tentar regenerar sua estrutura de forma, mais e mais, confusa e disfuncional, o tecido hepático vai aos poucos perdendo suas refinada arquitetura, substituída pela massa bruta da fibrose (tecido de estrutura grosseira). Quando a fibrose progride além de um certo ponto, passa a formar massas maiores, ditas nódulos, e a essa arquitetura pervertida e disfuncional corresponde o quadro clínico de cirrose.

Hora de jogar a toalha? Não, nunca. Pesquisas recentes começam a compreender melhor esse processo de destruição e regeneração desastrada através da análise de um sistema de regulação corporal denominado sistema renina-angiotensina (SRA). O SRA existe tanto no organismo como um todo, como dentro do próprio fígado. $\mathrm{Na}$ tentativa de reparar os sucessivos danos, o SRA, geral (sistêmico) e intra-hepático, acaba por provocar problemas adicionais que observamos em pacientes com cirrose, como ascite (abdomem muito dilatado e repleto de líquido) 
e aumento expressivo da pressão no sistema de vasos hepáticos e seus comunicantes, denominado sistema porto-cava (ou seja, a confluência entre dois grandes vasos, a porta e a cava, e seus afluentes). Por meio da inibição desse sistema e da utilização de medicamentos antiinflamatórios, estão sendo, no momento, elaboradas e avaliadas alternativas terapêuticas que buscam interromper a progressão da fibrose hepática e, mesmo, revertê-la, parcialmente. Há grandes esperanças quanto a estas novas estratégias, a serem utilizadas em um futuro próximo (ver capítulo 5).

Não poderia encerrar este capítulo sem mencionar brevemente o impacto positivo das minhas leituras recentes do pesquisador croata, naturalizado brasileiro, Radovan Borojevic. Rompendo com o esquematismo e o caráter estático de como nós, os estudantes de biologia e medicina dos idos do século passado, aprendemos tais questões, o autor trabalha com uma visão dinâmica e de fato estrutural (sob o paradigma da bioengenharia) da arquitetura dos tecidos. A partir da leitura dos seus trabalhos é possível compreender melhor o conjunto de ações frustradas de regeneração descritos, que nos parecem, a princípio, tão-somente desastradas, mas que estão em sintonia com a incapacidade de organismos adultos, em boa parte, já idosos, como os indivíduos majoritariamente afetados pela hepatite $\mathrm{C}$ crônica, membros de uma espécie biológica complexa (ainda que confusa), como nós, seres humanos, em regenerar tecidos de fina arquitetura destruídos pelas agressões contínuas. $O$ fato de as células hepáticas se multiplicarem lentamente, ao contrário, por exemplo, das células da epiderme (que compõem a nossa pele), faz com que uma ferida na pele cicatrize de forma rápida e eficiente, mas que este seja um processo lento e penoso quando a agressão tem lugar no fígado. 
Outro conceito trabalhado por Borojevic e colaboradores é de que cada arquitetura tecidual determina um padrão de interação específico com os demais elementos e estruturas do organismo, fazendo com que a progressiva desestruturação de um tecido, no caso, o tecido hepático, altere o conjunto de suas inter-relações com o organismo, inclusive com as células de defesa, como os linfócitos de memória que por lá circulam permanentemente. Portanto, a distorção de uma dada estrutura ou sistema não constitui nunca um fenômeno isolado, mas representa, de fato, um elo de uma cascata de eventos, que ainda não conhecemos em profundidade. Muito provavelmente, as distorções presentes num dado tecido fomentam a geração de distorções adicionais, processo, que, caso não seja interrompido, pode gerar quadros bastante disfuncionais, do ponto de vista biológico, e graves, do ponto de vista clínico.

Por outro lado, o conhecimento detalhado dessas interações subsidia a utilização, em um futuro ainda distante, de técnicas de bioengenharia tecidual, em que células-tronco serão utilizadas para recompor as estruturas danificadas. Tais procedimentos têm-se mostrado viáveis em lesões menos complexas do que as lesões que descrevemos acima, decorrentes da infecção crônica pelo vírus de hepatite C. Estão aí, portanto, as sementes do futuro. Cabe apostar nelas. 


\section{I Uma Túnica de Várias Cores}

Logo que José chegou a seus irmãos, estes o despiram da sua túnica, a túnica de várias cores, que ele trąia.

(Gen 37, 23)

Assim como as bíblicas roupas de José, a clínica da hepatite C é uma túnica de várias cores, bastante mais cores do que se supõe a princípio. Trata-se de uma túnica de várias cores, uma vez que as manifestações clínicas da hepatite $C$ se estendem para além da sua própria denominação “ 'hepatite (doença do fígado) -, constituindo-se na verdade em uma doença sistêmica (termo que designa doenças que abrangem vários órgãos e/ou sistemas de um organismo).

Não resta dúvida de que a hepatite $C$ é, antes de tudo, uma afecção que afeta o fígado, caso contrário sua denominação seria imprecisa e injustificada. No entanto, a hepatite $C$ habitualmente evolui com manifestações em diferentes órgãos e sistemas, como a pele, cavidade oral, pulmões, afetando, antes de tudo, a imunidade do indivíduo de forma abrangente, o que vimos no capítulo anterior. Vamos a essas manifestações, antes de retornarmos ao fígado propriamente dito.

$\mathrm{Na}$ obra Hepatite C: aspectos críticos de uma epidemia silenciosa, também publicada pela Editora Fiocruz, em 2005, são listadas 36 manifestações extra-hepáticas (ou seja, manifestações que não as hepáticas ou relativas ao fígado), de origem basicamente 
auto-imune (o que vimos em algum detalhe no capítulo anterior). Irei aqui resumir, de forma a mais clara e simples possível para o não especialista, que manifestações são essas. Grosso modo, poderíamos subdividi-las em agravos que afetam o organismo no seu conjunto, de forma menos específica, e manifestações que afetam preferencialmente determinados órgãos, mais especificamente.

Dentre as primeiras, cabe citar a fadiga (cansaço) crônica, manifestação que é muitas vezes confundida com questões psicossociais que, habitualmente, são consideradas (erradamente) como menos relevantes, como o desânimo, a tristeza e a depressão. Portanto, cabe investigar a infecção crônica pelo VHC em indivíduos que poderíamos designar apressadamente como 'pouco motivados' ou 'cansados'. Esta síndrome de fadiga pode se superpor às manifestações (também de cansaço e desânimo) secundárias a diferentes anemias, presentes com relativa freqüência na hepatite $\mathrm{C}$ crônica. Mais um motivo, portanto, para prestar atenção a esses sintomas, aparentemente vagos e subjetivos.

As manifestações auto-imunes podem se revestir de maior gravidade, afetando diferentes sistemas de forma mais agressiva, por exemplo, determinando inflamação de tendões e músculos (fibromialgias e poliomosite), diferentes estruturas do sistema nervoso e órgãos dos sentidos, como na Síndrome de Guillain-Barret. Tal síndrome é uma polirradiculopatia, isto é, inflamação de diversas raízes nervosas, afetando, habitualmente, a medula espinhal de forma progressiva, comprometendo terminações sensitivas e motoras, ou seja, com repercussões referentes à sensibilidade, com sintomas como formigamento e dor, e à capacidade de realizar movimentos) e nas uveítes (afecções que atingem os olhos, nas suas estruturas intermediárias e/ou profundas). 
Uma outra vertente possível de afecções sistêmicas associadas à hepatite $\mathrm{C}$ é a sobreposição do quadro hepático com quadros clínicos abrangentes, que podem ocorrer, nos demais indivíduos, de forma totalmente independente da hepatite $\mathrm{C}$ crônica, como as afecções que afetam os órgãos denominados linfohematopoiéticos, ou seja, os órgãos que estão associados à formação e fluxo de dois fluidos corporais, a linfa e o sangue. Neste último grupo, estão incluídos alguns linfomas (cânceres das células linfáticas). Estas manifestações, ainda que raras, podem estar presentes em alguns pacientes com hepatite $\mathrm{C}$ crônica, $\mathrm{O}$ que faz com que a investigação diagnóstica e o manejo clínico da hepatite $C$ devam ser os mais abrangentes possíveis, de modo que, na eventualidade de aparecimento dessas síndromes, haja pronto diagnóstico e tratamento.

Outras afecções atingem basicamente órgãos específicos, como os pulmões, ou regiões específicas do corpo, como a cavidade bucal. Nem sempre os especialistas, neste caso, os pneumologistas e os dentistas/estomatologistas, estão atentos às inter-relações entre os quadros que observam e tratam, e a hepatite C crônica. Neste sentido, vale a pena mencionar brevemente os principais quadros a ela associados.

No caso dos pulmões, as afecções associadas são antes decorrência dos efeitos colaterais do tratamento do que da hepatite C crônica por si só. Exceção feita a quadros de fibrose pulmonar, os demais problemas que afetam as vias respiratórias e os pulmões na hepatite $C$ crônica são, basicamente, conseqüências indesejáveis da terapia com o interferon e a ribavirina (quanto a este último medicamento, não há por ora clareza quanto a uma possível relação direta com complicações pulmonares), como veremos a seguir. 
Um dos quadros mais comuns, que, na minha experiência (limitada ao acompanhamento de usuários de drogas injetáveis, e, portanto, não necessariamente generalizável aos demais pacientes), vi e vejo com enorme freqüência é uma síndrome bastante similar à gripe, quando da administração do interferon. Os pacientes se queixam de mal-estar, dores musculares, febre e sintomas respiratórios variáveis, como, por exemplo, tosse e dificuldade de respirar. Habitualmente, esses sintomas são transitórios e se tornam menos presentes e incômodos à medida que o tratamento avança. Em algumas ocasiões, relativamente pouco freqüentes na minha experiência, é necessário interromper o uso da medicação.

Uma questão central à população com a qual venho trabalhando ao longo dos anos (como disse "os usuários de drogas, especialmente, de drogas injetáveis) é a administração simultânea da medicação e o consumo de drogas e álcool. Assim como no caso da infecção pelo HIV/Aids, não se deve, jamais, basear condutas clínicas em preconceitos e avaliações superficiais. Infelizmente, é bastante comum que profissionais de saúde excluam, a priori, pacientes com um histórico de uso de álcool e drogas de terapias antivirais para o HIV/Aids ou para a hepatite C crônica. Com isso, é possível que sejam indevidamente excluídos dos potenciais benefícios da terapia exatamente aqueles que dela mais necessitam, em função da gravidade dos seus quadros clínicos e de condições de vida adversas.

Estaria mentindo se dissesse que o manejo cotidiano de pacientes usuários de drogas e álcool, com hepatite C crônica ou $\mathrm{HIV} /$ Aids, e, freqüentemente, afetados por ambas as condições, constitui tarefa fácil. Muitos destes pacientes co-infectados necessitam de terapia antiviral combinada para ambas as condições 
"hepatite C crônica e Aids. No caso específico da Aids, a terapia é denominada anti-retroviral, por se tratar de um medicamento destinado a combater um retrovírus, o HIV, embora ambas as terapêuticas sejam, num sentido mais amplo, anti-virais, em se tratando de infecções por vírus.

Como o leitor virtual para quem escrevo não é, espero, aquele leitor a quem o poeta francês Charles Baudelaire se dirigiu, com fina ironia, em As Flores do Mal, ("meu leitor hipócrita, meu semelhante, meu irmão"), cabe mencionar tanto dificuldades como caminhos a serem trilhados.

Em primeiro lugar, na minha opinião pessoal, não há estratégia de 'redução de danos' (ou seja, não me parecem possíveis estratégias terapêuticas que não compreendam, necessariamente, a abstinência) em se tratando do consumo de álcool e uso de interferon no tratamento da hepatite $C$ crônica. Em relação a outras drogas, que não o álcool, é possível apostar numa redução gradual e, mesmo em certos casos, administrar, com cautela, a complexa situação em que determinados pacientes não conseguem se manter abstinentes no período em que estão sob terapia com o interferon. Obviamente, o ideal é que se mantenham abstinentes, mas nem sempre isso é possível no mundo real. Quanto ao álcool, a bibliografia especializada e a minha experiência apontam para efeitos desastrosos do seu uso concomitante com a medicação para tratamento da hepatite $C$ crônica na maioria dos casos. Isto ocorre muito possivelmente porque os pacientes, com longo histórico de uso crônico de álcool e hepatite $\mathrm{C}$ igualmente crônica, chegam para o tratamento em um momento que suas reservas hepáticas (a capacidade do fígado em desempenhar suas funções habituais, essenciais ao organismo como um todo) estão próximas do limite. 
Cabe lembrar que uma das causas mais importantes da cirrose hepática é o uso continuado, e em grandes quantidades, de bebidas alcoólicas, o mais das vezes associado à desnutrição, por razões que incluem a queda das reservas de tiamina (uma das vitaminas essenciais ao metabolismo do organismo, que integra o denominado complexo vitamínico B), a 'substituição', nos alcoolistas graves, da alimentação regular pela ingestão de bebidas alcoólicas (muito calóricas, mas pouco nutritivas de fato) e a interseção entre alcoolismo e más condições de vida e trabalho. Disse, com sua ironia habitual, o escritor irlandês Oscar Wilde, que não era verdade que o álcool fosse a praga das classes trabalhadoras, mas sim que o trabalho é que constituía uma praga que afetava as classes que bebem!

Por isto, sempre converso com os pacientes, antes de ser iniciada qualquer terapia medicamentosa para a hepatite $C$ crônica, que é absolutamente essencial que eles se abstenham do álcool. Quase invariavelmente a resposta deles é: "vou ver se dá para diminuir um pouco". Deve-se, entretanto, lançar mão de todos os argumentos e tentar inserir os pacientes em psicoterapia, além da terapia auxiliar com medicamentos psiquiátricos, como ansiolíticos (calmantes) e antidepressivos. Nem sempre esses esforços são bem-sucedidos e, ao longo dos anos, já perdi diversos pacientes. Ainda assim, creio que não devemos desistir, pois a desistência por parte do profissional de saúde é, muitas vezes, sinônimo de ajudar a empurrar o paciente para um beco sem saída. Diz um antigo ditado hebraico que "quem salva uma vida, contribui para salvar o mundo". Pela dificuldade da tarefa que temos pela frente nesses casos, não convém abrir mão dessa perspectiva, algo ingênua, mas profunda e, antes de tudo, ética e solidária. 
Retornando às complicações de natureza sistêmica (cabe recordar: afecções que afetam o organismo no seu conjunto), vem ganhando destaque na pesquisa recente a inter-relação entre hepatite $\mathrm{C}$ e diabetes. Por razões ainda não inteiramente claras, a hepatite $\mathrm{C}$ crônica habitualmente gera um quadro de resistência à insulina, hormônio que (de forma bastante simplificada) faz com que os açúcares entrem nas células do organismo, reduzindo, com isso, os níveis de açúcar na corrente sangüínea (e, eventualmente, em outros fluidos do organismo, como a urina). A falta de insulina faz com que as células não contem com o suprimento adequado de energia e que as quantidades por demais elevadas de açúcar diluído nos fluidos corporais lesem (ou seja, machuquem, firam) as paredes dos vasos por onde circula o sangue, como nas veias em geral, rins e pequenos vasos dos olhos.

Portanto, ao contar com um fator a mais de risco para o desenvolvimento do diabetes, os pacientes que não eram diabéticos antes do aparecimento da hepatite $\mathrm{C}$ crônica devem prestar especial atenção aos demais fatores de risco, como a ingestão excessiva de açúcares, a obesidade e o sedentarismo. Com relação aos pacientes que já eram diabéticos antes que a infecção pelo VHC se tornasse crônica, cabe um manejo cuidadoso de ambas as condições, com um trabalho integrado entre endocrinologistas e profissionais que cuidam da hepatite $C$, como hepatologistas ou gastroenterologistas. Cabe aqui uma breve observação, uma vez que afirmei no capítulo anterior que pesquisas recentes documentam que a exposição a diversos agentes infecciosos pode determinar uma proteção frente ao desenvolvimento da diabetes. É importante notar que, entre estas infecções, possivelmente protetoras, nas experiências com roedores, não se inclui a infecção pelo VHC (o vírus da hepatite C) e que, portanto, 
tudo indica que algumas infecções são protetoras com relação ao risco de desenvolver diabetes, mas não no caso da hepatite $C$ crônica, quando, ao invés de uma redução, ocorre, de fato, uma ampliação do risco de desenvolver diabetes.

A pele, apesar de não ser vista como tal pela maioria das pessoas, é nosso órgão mais extenso, e aquele que se situa na interface (junto com o tubo digestivo) entre o organismo e o meio ambiente. A pele costuma ser afetada por doenças não apenas inicialmente restritas a ela, mas também por doenças de natureza sistêmica que se expressam primeiramente como manifestações cutâneas, ou que, ao menos, o observador externo nota primeiro na pele, bem de acordo com a expressão corrente "isso está à flor da pele".

As manifestações cutâneas mais freqüentes na hepatite $C$ estão vinculadas a afecções sistêmicas, de natureza auto-imune, como boa parte das manifestações extra-hepáticas da hepatite C. As duas principais manifestações cutâneas da hepatite C crônica atendem por nomes tão estranhos, que soam aos ouvidos dos não-especialistas como verdadeiros quebra-cabeças. Os detalhes referentes a tais afecções fogem ao escopo deste livro, mas apenas para matar a curiosidade dos leitores em relação a nomes que disse soarem estranhos, pois não há quem não goste de nomes exóticos - aí estão eles “, estas afecções atendem, respectivamente, pelos nomes de crioglobulinemia mista e porfiria cutânea tarda. Bom, eu avisei que eram estranhos...

A cavidade bucal, assim como a pele, é uma estrutura em interação permanente com o meio ambiente, com a particularidade de ser a primeira instância da nossa relação cotidiana com os alimentos, além do seu papel na ingestão de medicamentos, líquidos e produtos eventualmente tóxicos, que ingerimos com 
propósitos 'recreativos' (como algumas drogas e o álcool) ou de forma inadvertida (como nas intoxicações involuntárias). Portanto, é relativamente freqüente, em determinados indivíduos vivendo com hepatite $C$ crônica, uma superposição de diferentes fatores que podem afetar a cavidade bucal, como manifestações associadas mais diretamente à hepatite $\mathrm{C}$ crônica, como o líquen plano (doença crônica cujo detalhamento foge aos propósitos deste livro e à competência do seu autor), sinais e sintomas associados ao uso prolongado de diferentes medicações, como a sensação de náusea e a azia, e problemas derivados do consumo contínuo do álcool e outras drogas, bastante freqüentes entre os usuários de drogas injetáveis, como inflamação gengival (habitual em pacientes que alternam a injeção de cocaína com a auto-administração da cocaína pelas mucosas nasal e oral, muitas vezes com o uso simultâneo do álcool). Não por acaso, por trabalhar com indivíduos infectados pelos vírus da Aids e da hepatite $\mathrm{C}$ que fazem uso de drogas injetáveis, encaminho tais pacientes com enorme freqüência ao dentista, quando não ao dentista e ao estomatologista (médico especializado na cavidade oral e suas patologias).

Já não era sem tempo de voltar às afecções propriamente hepáticas, afinal, trata-se, apesar de toda diversidade, de uma hepatite. Recapitulando o que vimos, sob outros prismas, nos capítulos anteriores, a infecção pelo VHC se manifesta inicialmente de modo muito variável. A hepatite aguda pelo VHC tem sintomatologia, em geral, branda, que é, na maioria dos casos (estima-se que a infecção aguda seja assintomática em 80\% dos indivíduos), tão branda a ponto de nem ao menos ser notada pelo indivíduo por ela afetado. Em uma minoria de casos, a infecção aguda pode se manifestar com quadros sintomáticos, 
especialmente com náuseas, diarréia, perda de apetite, dor na região em torno do fígado (quadrante superior direito do abdômen), icterícia (cor amarela nas mucosas, como, por exemplo, nas conjuntivas dos olhos), urina escura e fezes claras.

Como, habitualmente, a infecção aguda não é notada pelos indivíduos por ela afetados nessa fase inicial, muitas vezes a infecção, já persistente, é observada de forma casual, muitos anos depois do episódio de infecção aguda, por meio de um exame laboratorial de rotina.

Algumas pessoas eliminam espontaneamente o vírus da hepatite $\mathrm{C}$ após apresentarem um episódio agudo de infecção (ver desdobramentos desse raciocínio no capítulo 5). Não se sabe ainda com certeza que fração dos infectados consegue eliminar definitivamente os vírus, assim como ainda é objeto de pesquisa como e quais pessoas conseguem fazê-lo. Uma das razões pelas quais é tão difícil saber quantas pessoas eliminam o vírus da hepatite $\mathrm{C}$ e como o fazem, em cada etapa da sua resposta imunológica à infecção, deriva justamente do fato de a imensa maioria das infecções agudas ser assintomática, fazendo com que grande parte das avaliações seja retrospectiva, com uma defasagem no tempo de décadas, com relação ao período em que ocorreu a infecção aguda. É possível seguir no tempo populações sob especial risco de infecção pelo VHC, como os usuários de drogas injetáveis, mas fica a questão de o quanto tais achados, relativos a uma população com características tão específicas, podem ser extrapolados para as demais pessoas afetadas pela hepatite C.

Enfim, a despeito das limitações e imprecisões, sabe-se que a maioria das pessoas evolui para uma infecção persistente no tempo, embora apenas uma minoria venha a apresentar, ainda que transcorridas décadas, quadros graves. 
Os principais fatores de uma evolução mais grave, à parte do próprio transcurso do tempo e do envelhecimento dos indivíduos (com o conseqüente enfraquecimento das suas defesas imunológicas), são: ser do sexo masculino (ou seja, observa-se uma evolução mais favorável entre as mulheres), consumir, de forma abusiva, bebidas alcoólicas e co-infecção com o vírus da Aids. Mais recentemente, fatores vinculados ao metabolismo e ao estado de saúde de um modo geral têm sido estudados com maior detalhe, chamando-se atenção para o papel da obesidade, do diabetes e da presença de gordura no fígado (esteatose), como fatores que podem levar a uma progressão mais grave e acelerada dos quadros de fibrose hepática (vide capítulo 2).

Portanto, cresce a relevância de fatores relacionados a um estilo de vida mais ou menos saudável. Como grande parte das pessoas não sabe estar infectada, cabe raciocinar como nas promoções comuns em supermercados: "pague 1 e leve 2", ou seja, o indivíduo apostaria em um estilo de vida mais saudável de um modo geral, com reflexos positivos sobre o seu metabolismo e especialmente sobre o aparelho cardiovascular. Na eventualidade de ele vir a se infectar, em algum momento da vida, com o VHC, o prognóstico da infecção será mais favorável, ainda que ele nem ao menos saiba disso.

Os indivíduos com uma infecção crônica ativa, com inflamação persistente do fígado, evoluem com graus variáveis de fibrose, distorção da arquitetura original do fígado e perda da capacidade funcional do órgão. Algo como $20 \%$ dos indivíduos com infecção crônica pelo VHC progride para um quadro grave de fibrose difusa (espalhada por diversas áreas do fígado) e cirrose (a expressão clínica de quadros de fibrose avançada). A cirrose habitualmente se manifesta plenamente após três décadas de evolução 
da infecção crônica, em não mais do que $10 \%$ de todos os pacientes com infecções crônicas pelo VHC.

Uma pequena fração de indivíduos, mas muito relevante do ponto de vista clínico e de saúde pública, devido à gravidade do quadro, pode vir a desenvolver o câncer hepático.

$\mathrm{O}$ advento da terapia com o interferon representa um marco na moderna terapia da hepatite $\mathrm{C}$ crônica e uma mudança no paradigma da saúde pública com relação a esta epidemia. De uma condição que só podia ser prevenida, pelo controle dos estoques de sangue e pela mudança comportamental (por exemplo, evitando a transição do uso não injetável para injetável de drogas), passou-se a uma doença tratável, ganhando ênfase os aspectos de diagnóstico precoce, oferta ampla e gratuita de um tratamento sabidamente dispendioso, aderência ao tratamento e monitoramento cuidadoso do mesmo.

Interferon é, na verdade, uma designação genérica para um amplo grupo de substâncias (proteínas) secretadas pelas células do sistema imunológico, além de outras células do organismo, sob diferentes modalidades. Estas modalidades de interferon são classificadas em três grandes classes (I, II, III). A classe I é a mais numerosa e se subdivide em subclasses, representadas por letras gregas (como alfa e beta). O interferon utilizado no tratamento da hepatite é o interferon alfa, e sua variante (a partir de manipulação da sua estrutura e apresentação) denominada interferon peguilado (nas modalidades alfa $2 \mathrm{a}$ e alfa $2 \mathrm{~b}$ ).

A resposta aos diferentes interferons depende basicamente das variantes dos vírus (mais ou menos agressivas) que infectam os diferentes pacientes e das condições de saúde do paciente sob tratamento. É fundamental que o paciente se mantenha aderente ao tratamento, a despeito do eventual aparecimento de 
efeitos colaterais, se abstenha do uso do álcool e seja monitorado cuidadosamente. O tratamento com interferon é comumente associado ao emprego da ribavirina. A ribavirina é um potente antiviral, ativo contra diversos vírus, como o da gripe (influenza) e o VHC, que atua através da inibição da reprodução dos vírus.

Para finalizar, mostra-se especialmente trágica e desafiadora a constatação de que, nos dias de hoje, especialmente nos países em desenvolvimento (onde a hepatite $\mathrm{C}$ é especialmente prevalente), a principal limitação ao efetivo tratamento da hepatite $C$ seja de natureza financeira. $\mathrm{O}$ interferon peguilado (o medicamento mais efetivo) está protegido por patentes das companhias farmacêuticas internacionais, e é vendido por preços muito elevados. Habitualmente, o paciente individual e sua família não têm como arcar com os custos do tratamento e o sistema público de saúde, de países como o Brasil, se vê às voltas com dificuldades de manter um estoque regular, para um número crescente de pacientes (ver detalhes no capítulo 4). O resultado são imensas filas de espera, descontinuidade no tratamento, dificultando sobremaneira o sucesso da terapêutica. A grande maioria dos países em desenvolvimento conta hoje com um expressivo contingente de portadores da hepatite $\mathrm{C}$ crônica não tratados ou tratados de forma insatisfatória. Tais limitações e deficiências têm reflexos tanto sobre a saúde dos indivíduos como da coletividade.

Como veremos em detalhe no capítulo subseqüente, pacientes não tratados e/ou tratados de forma insatisfatória podem constituir fontes de novas infecções, influenciando, portanto, a dinâmica da epidemia como um todo. Ainda que o tratamento esteja longe de uma eficácia de 100\%, não resta dúvida de que ele reduz a carga de vírus circulantes de uma proporção 
substancial de pacientes e, com isso, reduz o número de potenciais infectantes (pessoas que, eventualmente, podem ser a fonte de novas infecções).

O Brasil e outros países em desenvolvimento estão apostando no desenvolvimento da tecnologia nacional e da cooperação sul-sul (ou seja, entre diferentes países em desenvolvimento) para baratear os atuais custos e tornar o tratamento para a hepatite $\mathrm{C}$ uma realidade para as inúmeras pessoas que dele precisam. Só assim transformaremos em realidade o conceito que norteia nosso sistema de saúde e que está inscrito na Constituição, de que a saúde é um direito de todos. 


\section{$4 \mid$ Mundo, Mundo, Vasto Mundo...}

Como não me chamo Raimundo, mas sim, Francisco, estou longe de servir de rima (como queria Carlos Drummond de Andrade com relação ao Raimundo do famoso "Poema de sete faces"), e muito menos ter solução para a incrível complexidade da epidemia pela hepatite $\mathrm{C}$ em todo o mundo.

O conhecido lugar-comum, que anuncia que "as coisas tendem a piorar, até que comecem a melhorar", infelizmente, traduz em linguagem simples o curso em um futuro imediato da epidemia de hepatite $\mathrm{C}$ em todo o mundo, de acordo com a maioria dos especialistas na questão. Explica-se: em se tratando de uma doença de evolução especialmente lenta, que se mantém inteiramente assintomática por anos a fio, não resta dúvida de que lidamos hoje com a ponta de um iceberg cujas dimensões não conhecemos ao certo. Esta ponta do iceberg corresponde aos casos de hepatite $\mathrm{C}$ crônica hoje identificados, seja porque, devido a alguma eventualidade, estes indivíduos fizeram exames de rotina, ou porque, em algum momento das suas vidas, se mostraram sintomáticos e procuraram os serviços de saúde (cabendo observar que inúmeras pessoas, especialmente nos países mais pobres, não têm acesso algum aos serviços de saúde) para se tratar.

Junte-se a isso a elevada prevalência da hepatite $C$ em países de imenso contingente populacional, como a China e a Indonésia, onde o acesso aos serviços de saúde é precário em diversas 
áreas, como nas periferias superpovoadas das grandes cidades e nas áreas rurais, além do fato da epidemia, nestes países e em todo o mundo, estar concentrada em populações de difícil acesso, avessas ao contato com os serviços de saúde (por serem ou temerem ser discriminadas), como os usuários de drogas injetáveis.

Como se tudo isso não bastasse, há ainda que considerar o que foi mencionado no capítulo 1 , que a epidemia progrediu de forma silenciosa ao longo de boa parte da década de 80, quando os controles dos estoques de sangue para o vírus da hepatite $\mathrm{C}$ inexistiam (pois a doença não era conhecida e/ou não havia testes capazes de detectar a presença da infecção no sangue) ou funcionavam de forma muito precária, especialmente nos países em desenvolvimento, onde se concentra a imensa maioria dos habitantes do planeta terra.

Enfim, até que se façam sentir os efeitos positivos de um melhor conhecimento da doença, do controle efetivo dos bancos de sangue, da oferta de tratamentos modernos (o que mobilizaria os potenciais interessados a que, de fato, procurassem os serviços de saúde e/ou exigissem seus direitos a um tratamento adequado), conquistas datadas dos anos 90 e da presente década, a epidemia da hepatite $\mathrm{C}$ tende a se agravar, em todo o mundo, ao longo da presente década, mais indivíduos, infectados na década de 80, adoecerão, após anos de persistência de infecção assintomática.

Como a maior pressão por tratamento, ao longo dos próximos anos, deverá ocorrer de forma especialmente marcante nos países em desenvolvimento, muitos deles bastante populosos, e, em países desenvolvidos, exatamente entre os segmentos sociais mais pobres e marginalizados, trata-se de uma crise no âmbito da saúde pública de grandes proporções. 
Caso fosse possível abortar grande parte dos quadros mais graves com o tratamento efetivo das pessoas cronicamente infectadas pelo VHC, evitar-se-iam conseqüências mais sérias e potencialmente insolúveis no contexto dos países mais pobres, como o tratamento da cirrose e do câncer hepático por intermédio de métodos complexos e dispendiosos, como a quimioterapia para o câncer ou o transplante hepático. No entanto, para que isso acontecesse, seria necessário ampliar substancialmente a busca ativa (ou seja, o inverso de sentar e esperar que os pacientes apareçam espontaneamente nos serviços) de pessoas infectadas e oferecer tratamento a todos que dele necessitassem.

Tais medidas envolvem dificuldades substanciais do ponto de vista logístico, de como organizar os serviços de saúde para oferecer atendimento amplo e de qualidade; ético, o que compreende a necessidade de oferecer tratamento uma vez que sejam testados os indivíduos, e técnico-financeiro, no que diz respeito a criar condições de tratar e monitorizar um enorme contingente de pessoas e de financiar de forma sustentável em longo prazo essas ações. De fato, é preciso juntar muitos "Raimundos", mundo afora, para que encontremos alternativas para a resolução de problemas tão complexos.

\section{Depois DA TEMPESTADE... VEM A BONANÇA}

Alguns achados da modelagem matemática podem soar como cruéis, ao divisar horizontes promissores a quem está atolado em problemas presentes. Na verdade, a matemática, sempre tão pura e precisa, não tem culpa no cartório, quem tem somos nós, seres humanos, que não apenas formulamos teoremas matemáticos, mas, com maior freqüência do que seria imaginável, negamos qualquer auxílio ao próximo. 
Seja como for, e façamos o que fizermos, em longo prazo, a epidemia de hepatite $C$ deverá arrefecer em praticamente todo o mundo, o que talvez pareça uma espécie de mágica perversa frente ao quadro desalentador que descrevi em alguns parágrafos anteriores. Mas, me explico: trata-se de uma tendência para um futuro mais longínquo, a famosa bonança que se segue à tempestade no ditado popular, que, reconheço, não serve de consolo a quem está no meio de uma tempestade.

Mas, vamos por etapas... Tento, a seguir, utilizar na discussão alguns conceitos da epidemiologia matemática sem recorrer a qualquer número ou equação. Espero que dê certo, e que as tendências contrastantes descritas anteriormente possam ficar mais claras para o leitor.

$\mathrm{Na}$ epidemiologia da hepatite $\mathrm{C}$, um componente absolutamente essencial da transmissão é o contato com o sangue contaminado. Como mencionado brevemente no capítulo 1, no âmbito da saúde pública, o papel do sangue contaminado na transmissão da hepatite $C$ é muito mais relevante, do que, por exemplo, na hepatite B ou na Aids. Se houvesse um controle hipotético de toda a transmissão sangüínea, a epidemia da hepatite $C$ sofreria um duríssimo golpe, enquanto a Aids e a hepatite $\mathrm{B}$ teriam sua dinâmica certamente reduzida, mas seguiriam sendo transmitidas através das relações sexuais. $\mathrm{Na}$ verdade, o que é transmitido são os vírus, e não as doenças. Quando se fala em transmitir doenças nos rendemos à força da expressão cotidiana.

Portanto, em termos de hepatite C, alterar drasticamente os riscos associados à transmissão de sangue e dos seus produtos derivados (conhecidos pela designação de hemoderivados) representa uma mudança profunda na dinâmica da epidemia. $\mathrm{E}$ isso, de fato ocorreu, e com uma abrangência bastante grande, 
ao longo da década de 80 . Pressionados pelos ativistas no campo do HIV/Aids em todo o mundo, os governos se viram forçados a fechar bancos de sangue irregulares, implementar o uso de testes confiáveis para o HIV/Aids (e, de forma menos sistemática e mais lenta, para outras doenças, como as hepatites B e C) e proibir, em diversos países, a prática de trabalhar com doadores profissionais remunerados, habitualmente recrutados entre pessoas marginalizadas e às voltas com taxas altíssimas de infecção pelos mais diferentes agentes infecciosos.

Tais mudanças foram muito relevantes em todo o mundo, e, ainda que com um certo atraso e descontinuidades, há que reconhecer: o controle de sangue na imensa maioria dos países atingiu níveis de excelente qualidade, mesmo em grande parte dos países africanos, que não apenas têm sido duramente afetados pelas duas epidemias, da Aids e da hepatite C (além da malária, da tuberculose etc., mas isso já é matéria para um outro livro), como contam com os sistemas de saúde mais precários em todo o mundo.

Enfim, não resta dúvida de que a epidemia de hepatite $C$ sofreu um sério revés com o adequado controle de sangue, revés cujos reflexos se farão sentir nas décadas por vir, uma vez que, como disse no capítulo 3, a evolução de alguém cronicamente infectado com o VHC para a cirrose dura, em média, trinta anos! Portanto, estamos vivenciando hoje, em 2007, os reflexos da crise do controle do sangue dos anos 80 , crise esta que está longe de acabar e que, muito pelo contrário, se estenderá, pelo menos, até 2010-2015, quando grande parte das pessoas infectadas nos anos 80 terá completado o percurso de evolução da infecção crônica pelo VHC “ tendo a maioria desses quadros evoluído de forma relativamente benigna (sem problemas 
mais graves de saúde), em contraposição a uma minoria de pacientes que terá evoluído para quadros mais graves, como a cirrose e o câncer hepático.

Creio que o leitor já pode vislumbrar um dos porquês da anunciada bonança, que sucederá à tempestade. Ou seja, equacionada, em boa medida, a questão da qualidade dos estoques de sangue tende a arrefecer, em longo prazo, o efeito devastador da total falta de controle observada ao longo da década de 80 . Mas a questão está longe de ser respondida, pois, como disse no início do capítulo, a epidemiologia da hepatite $\mathrm{C}$ é extremamente complexa, e os leitores já estariam provavelmente me chamando de mentiroso se tudo estivesse resolvido em um único parágrafo e algumas poucas palavras. Há novos desafios a serem mencionados e eventualmente equacionados: vamos a eles!

Em primeiro lugar, a dinâmica favorável, da epidemia, a longo prazo, de nada adianta para resolver os problemas a curto prazo, e esses são gravíssimos, como a necessidade de ampliar a testagem, a oferta de tratamento, a redução substancial dos custos do tratamento e o treinamento de equipes de saúde no manejo e monitorização de vastos contingentes de pacientes vivendo com hepatite $\mathrm{C}$ crônica em todo o mundo. Este último desafio compreende tanto sensibilizar as equipes de saúde em lidar com populações marginalizadas, como os usuários de drogas injetáveis, quanto atualizá-las, permanentemente, com relação a um tratamento complexo e bastante dinâmico, em que, constantemente, aparecem novos esquemas terapêuticos e novos medicamentos (vide novas perspectivas de tratamento no capítulo 5). Ou seja, desafios à vista!

Mas, em segundo lugar, cabe observar que a questão do sangue contaminado está apenas parcialmente resolvida com o ade- 
quado controle dos bancos de sangue. E aqui retorna à cena um dos nossos personagens centrais, o usuário de drogas injetáveis, e entra em cena, como que de surpresa, um segundo personagem, o paciente medicado com injeções não estéreis. Abordarei inicialmente a questão dos usuários de drogas, por já fazerem parte do elenco da peça, aquilo que os antigos teatrólogos, como Shakespeare, denominavam pela bela expressão latina, dramatis personae, ou seja, as personagens do drama. Interessante observar que, apesar da raiz comum das palavras "pessoa" e "personagem", tendemos a distinguir radicalmente pessoas e personagens, estes últimos habitualmente reservados a alguém que só vive de mentirinha, nas obras de ficção, como romances e peças teatrais. Acontece que o drama que estou descrevendo aqui é feito de pessoas, pessoas de carne e osso, como nós, autor e leitores. Completando as homenagens aos imortais poetas ingleses, faço minha a pergunta de John Donne: "por quem os sinos dobram?"..., tendo respondido ele: "eles dobram por ti!?" (não posso me furtar a reproduzir o original, de uma sonoridade belíssima: "never send to know for whom the bell tolls; it tolls for thee...”). Mas deixemos de poesia, e voltemos à vã epidemiologia.

Os usuários de droga injetáveis freqüentemente compartilham agulhas e injeções, além de outros equipamentos/materiais (como algodões utilizados na filtragem de líquidos contendo drogas), líquidos e recipientes, utilizados no preparo e auto-administração de diferentes drogas, como a cocaína e a heroína. Por razões diversas, que vão de um certo espírito corporativo (isso mesmo!; não somos só nós, professores universitários, pesquisadores, advogados e médicos que constituímos corporações e vemos nesses grupos algo de relevante a que pertencer) à escassez de recursos e de equipamentos de injeção, fato é que os 
usuários de drogas freqüentemente se injetam com equipamentos contendo restos de sangue contaminado de outros usuários de drogas. Basta pensar que o fazem repetidas vezes, freqüentemente na companhia de diversas pessoas, muitas delas infectadas por diferentes agentes infecciosos, e teremos aí o que em epidemiologia denominamos "cadeia de transmissão", de incrível eficiência, eficiência esta mensurada do ponto de vista da ameaça concreta à saúde pública, além das perspectivas dos próprios vírus, caso estes tivessem pontos de vista.

Nos países desenvolvidos e em alguns dos países em desenvolvimento, como o próprio Brasil, além de países do Leste europeu e do sudeste de Ásia, os usuários de drogas injetáveis representaram uma população essencial à disseminação, tanto da hepatite $\mathrm{C}$ como do HIV/Aids, ao longo das últimas décadas. Com relação a eles, obviamente, as medidas de controle de sangue surtiram efeito limitado, ou seja, elas influenciaram os usuários de drogas enquanto possíveis recebedores de doações de sangue e enquanto doadores profissionais de sangue, nos países em que a doação remunerada foi efetivamente proibida, mas não alteraram em nada a dinâmica de práticas à margem da legislação referente ao controle do sangue. Conversei, quando comecei a trabalhar nessa área, com diversos usuários de drogas injetáveis que haviam sido doadores de sangue profissionais, praticamente todos eles infectados por microorganismos os mais diversos, e que só paravam de doar quando suas veias entravam em colapso, pela injeção repetida de cocaína, um poderoso irritante das veias.

Mas tudo muda, e os usuários de drogas também mudaram e mudam, e isso na contramão dos que as pessoas em geral acreditam " que eles seriam impermeáveis às mudanças, sejam 
elas espontâneas ou induzidas por terceiros, isto é, secundárias a mudanças de atitudes e comportamentos de natureza basicamente pessoal ou em decorrência das inúmeras iniciativas de prevenção implementadas nestas últimas décadas. Seja por medo, conscientização, pressão externa, não resta dúvida de que os usuários de drogas injetáveis, em diferentes partes do mundo, deixaram, em grande medida, de serem propriamente usuários de drogas injetáveis (ou seja, passaram a ser usuários de drogas por outras vias ou simplesmente passaram a se abster de quaisquer drogas, injetáveis ou não) ou reduziram substancialmente seus comportamentos de risco, como compartilhar agulhas e seringas.

Uma questão fundamental, no caso da infecção pelo VHC/ HCV (vírus da hepatite C) é que esta mudança tem de ser muito precoce no tempo. Existem duas alternativas neste caso: na primeira alternativa, o indivíduo jamais vem a se injetar, ou seja, jamais passa pela assim denominada transição de via de uso, mantendo-se sempre afastado das drogas injetáveis (seja consumindo drogas exclusivamente por outras vias ou se abstendo de usar quaisquer drogas). Na segunda alternativa, o indivíduo deve se prevenir de imediato e de forma absolutamente consistente, ao longo do tempo. Isso porque o vírus da hepatite $\mathrm{C}$ é muito mais infectante por via sangüínea do que seus confrades VHB/ HBC (vírus da hepatite B) e HIV/VIH (vírus da Aids). Um estudo bastante interessante desenvolvido na cidade de Baltimore, EUA, ilustra bem tal fato (Figura 1). 
Figura 1 - Prevalência da infecção pelo HIV e dos vírus das hepatites $\mathrm{B}$ e C em uma população de usuários de drogas injetáveis em Baltimore. EUA - 1983-1988
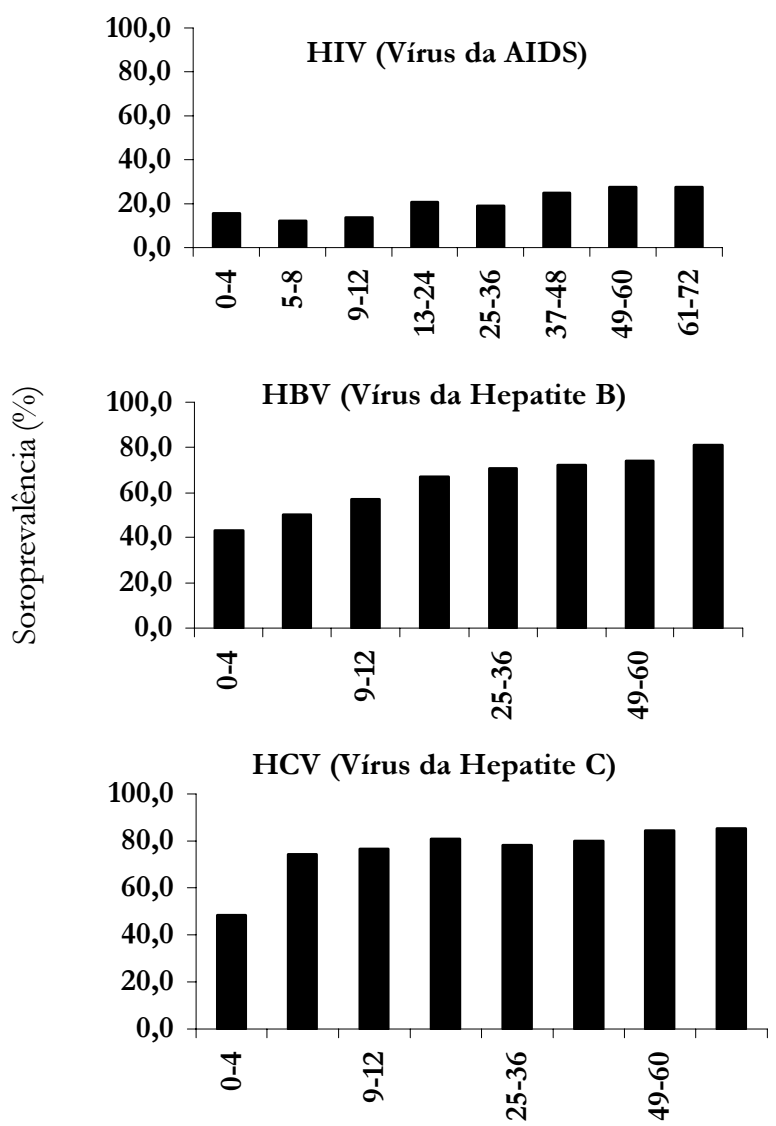

Duração (Meses)

Fonte: Adaptado de Garfein, R. S. et al. Viral infections in short-term injection drug users: the prevalence of the hepatitis $\mathrm{C}$, hepatitis $\mathrm{B}$, human immunodeficiency, and human T-lymphotropic viruses. American Journal of Public Health, 86(5): 655-661, 1996. 
Os autores seguiram, ao longo de seis anos, um grande contingente de usuários de drogas injetáveis. Como é possível observar na Figura 1, ao longo de uns poucos meses, uma proporção muito elevada de indivíduos já havia se infectado com o vírus da hepatite $C$ (e, em proporção algo menor, com o vírus da hepatite B). As taxas de infecção vão, progressivamente, se elevando, até atingirem valores elevadíssimos, quando mais de $80 \%$ dos usuários de drogas injetáveis sob acompanhamento se encontram infectados por ambos os vírus. O contraste com a infecção pelo vírus da Aids é marcante. Neste último caso, não apenas as taxas se elevam bem mais lentamente, com algumas flutuações de pequena monta, como atingem, ao final de um período de acompanhamento bastante longo, taxas substancialmente mais baixas.

O leitor perspicaz deve estar se perguntando: que as taxas de infecção pelo vírus da Aids cresçam mais lentamente, tudo bem, isso é possível compreender, mas como podem apresentar pequenos declínios? Não deveriam apenas crescer, progressivamente, ainda que de forma mais lenta? $\mathrm{Na}$ verdade, tal dinâmica é facilmente explicável pelo fato de um estudo desta natureza (tecnicamente denominado estudo de coorte) perder pacientes ao longo do tempo, seja por abandono, interrupção do uso de drogas, adoecimento (o paciente não tem mais disposição para seguir no estudo e o abandona, ou prioriza seu tratamento e não mais o acompanhamento no estudo) ou morte (em função das próprias infecções ou não, devido à violência ou às overdoses).

No caso de vírus que afetam os indivíduos de forma progressiva no tempo (note-se que não se trata aqui de monitorizar o adoecimento, mas sim as diferentes infecções), essas perdas podem se traduzir em flutuações para baixo, caso as pessoas 
que foram perdidas sejam, preferencialmente, pessoas infectadas. caso se tratasse não de infecção, mas sim de adoecimento, que, nesse caso, representa, antes de tudo, uma chance aumentada de abandono do estudo, teríamos uma situação inversa, com os indivíduos infectados pelo hcv/vhc adoecendo mais lentamente, em relação aos demais.

No caso da hepatite $C$, a velocidade extremamente elevada com que as pessoas se infectam torna essas perdas e flutuações para baixo pouco ou nada relevantes. Com isso, em prazos relativamente breves, a situação só tende a se deteriorar mais e mais. A longo prazo, tudo dependerá da oferta de tratamento e da recuperação efetiva de uma fração dos infectados.

Resolvida essa questão, estamos às voltas com outra pergunta: e por que isto se dá dessa forma? A resposta é: a capacidade de infectar (a infectividade) do vírus da hepatite $C$ por via sangüínea é muito mais elevada do que a do vírus da Aids. Portanto, nesta população, a disseminação é muito mais veloz com relação à hepatite $\mathrm{C}$ (como também à hepatite $\mathrm{B}$ ) do que ao vírus da Aids. Se estivéssemos lidando com uma população que não utiliza drogas injetáveis (de forma compartilhada), teríamos um quadro absolutamente distinto, com uma disseminação especialmente lenta, por via sexual e vias complementares (como, possivelmente, pelo compartilhamento de canudos utilizados na aspiração de cocaína; vide capítulo 1), do vírus da hepatite C.

Mas, em se tratando de uma população de usuários de drogas injetáveis, a dinâmica é totalmente dominada pela transmissão sangüínea. Isto não significa que a transmissão sexual não seja relevante (especialmente no caso do vírus da Aids), mas é que a transmissão sangüínea é tão eficiente nesta população (ao injetar quantidade expressiva de vírus direto na corrente sangüínea), que a transmissão 
sexual é pouco relevante em termos agregados (o que não quer dizer que um dado indivíduo ou subgrupo de indivíduos não possa se infectar por via sexual, mesmo nesta população). $\mathrm{Na}$ verdade, análises minuciosas de grandes contingentes de usuários de drogas injetáveis evidenciam claramente o diferencial representado pela transmissão sexual, ainda que análises mais simples e com números menores de indivíduos não consigam documentar o papel da transmissão sexual nesta população. A força da transmissão sangüínea é, simplesmente, avassaladora.

Em um trabalho de 2005, nosso grupo de pesquisa discutiu tais achados sob a perspectiva dos usuários de drogas injetáveis de três cidades brasileiras: Rio de Janeiro, Salvador e Santos (disponível em: <www.scielo.br/scielo.php?script=sci_arttext \&pid=S0074-02762005000100017\&tlng=es\&lng= en\&nrm $=$ iso $>$ ). Ainda que tais usuários de drogas não tivessem reduzido a proporção com que, uma vez injetando, viessem eventualmente a compartilhar equipamentos de injeção, haviam reduzido, substancialmente, a própria freqüência de injeções. Com isso, em se tratando de uma mudança que haviam empreendido ao longo dos anos, as suas taxas de infecção se reduziram de forma marcante. Como seria de se esperar, não haviam, no entanto, se transformado em abstinentes sexuais. Aliás, as únicas pessoas em todo o mundo que ainda acreditam na abstinência sexual como estratégia de prevenção da Aids em populações como os usuários de droga injetáveis são os formuladores das políticas preventivas que assessoram o presidente norte-americano George W. Bush; mas, ao que parece, os usuários de drogas brasileiros votariam com o Partido Democrata.

Ora, o que esperaria encontrar então o leitor atento às sutilezas da epidemiologia? Recapitulemos: da Aids (e da hepatite B) 
subtraiu-se, com as mudanças descritas anteriormente, um meio de transmissão relevante (o sangue), mas pouco ou nada alteramos no que diz respeito à transmissão sexual. Já com relação à hepatite $\mathrm{C}$, golpeou-se a via de transmissão absolutamente central, o sangue! Ora, onde esperaríamos encontrar reduções mais pronunciadas das taxas de infecção? $\mathrm{Na}$ hepatite $\mathrm{C}$, ora bolas! Pois foi exatamente isso o que encontramos no nosso estudo. $\mathrm{O}$ leitor curioso, que consultar o original, observará que a questão é mais sutil do que o que foi aqui exposto, devido às complexas interações entre a população de usuários de drogas ao longo do tempo, seus hábitos e as próprias características das cenas de uso e dos diferentes agentes infecciosos ao longo de condições ecológicas igualmente dinâmicas. Mas isso nos levaria muito longe. Aos interessados, recomendo consultar o trabalho original, em que essas questões são discutidas em detalhe (ver Bastos, F. I, et al. Is human immunodeficiency virus/acquired immunodeficiency syndrome decreasing among Brazilian injection drug users? Recent findings and how to interpret them. Memórias do Instituto Oswaldo Cruv, 100(1): 91-6, 2005).

Exatamente no momento em que escrevo este capítulo (janeiro de 2007), acaba de sair um artigo do pesquisador norteamericano Don des Jarlais e equipe, que mostra fenômeno em tudo similar em Nova York. Lançando mão de amostras gigantescas de usuários de drogas (perfazendo o incrível total de 2.500 entrevistados), que chegam a humilhar a nós, pesquisadores brasileiros, que trabalhamos, no máximo, com amostras de usuários de drogas na casa de umas poucas centenas, ele discute o fenômeno que denomina, de forma especialmente elegante (o que talvez surpreenda o leitor, que aposta, no máximo, na precisão da ciência. Mas, acredite-me, leitor, a ciência 
pode ser extremamente elegante, ainda mais em Nova York e orçada em dólar) "convergência de taxas".

A convergência de taxas é, nada mais nada menos, que a aproximação das taxas de infecção entre usuários injetáveis e não injetáveis. $\mathrm{Ou}$, dito de outra forma, usuários injetáveis que continuam a usar drogas, mas que praticamente não mais injetam, ou que, quando injetam, não compartilham, convergem para os padrões dos usuários não injetáveis. As taxas de infecção dos entrevistados de Des Jarlais e sua equipe se mostraram praticamente idênticas entre usuários injetáveis e não-injetáveis. Sem o sangue (não mais compartilhado por usuários que deixaram de injetar drogas em comum e/ou reduziram drasticamente a freqüência das suas injeções), quem move hoje, então, a epidemia entre os usuários de drogas nova-iorquinos? O sexo e outros hábitos arriscados de consumir drogas (como compartilhar canudos na aspiração de cocaína), ao que tudo indica.

Recapitulemos, então, tudo outra vez. Os estoques de sangue foram devidamente controlados, os usuários de drogas injetáveis mudaram seus comportamentos; estaríamos, então, no melhor dos mundos? Receio dizer que ainda não, caro leitor. Em primeiro lugar, centenas de milhares de usuários de drogas injetáveis estão hoje infectados por múltiplos vírus. Somem-se a isso suas condições de vida, quase sempre adversas; o consumo concomitante de doses generosas de álcool, a sua conhecida aversão pelos serviços de saúde formais (onde temem ser fichados e presos ou, no mínimo, discriminados) e a desconfiança dos profissionais de saúde com relação a estes pacientes quase sempre rebeldes, e temos uma situação grave em saúde pública, que vivencio a cada semana em que atendo esses pacientes. 
Com o progresso inequívoco das terapias para a Aids e os progressos também inquestionáveis com relação ao tratamento da hepatite $\mathrm{C}$, resta o desafio de tratar pacientes acometidos por ambas as infecções, simultaneamente, progredindo, ambas, ao longo de décadas, debilitando, ambas, os organismos dos indivíduos por elas afetados. Ainda que também aqui não caiba o desânimo, não resta dúvida de que a comorbidade Aids-hepatite $\mathrm{C}$ crônica representa o grande fantasma a tirar meu sono e o de todos que trabalham com a população de usuários de drogas, nos mais diferentes cantos do planeta. Como vêm mostrando os pesquisadores franceses que integram um amplo estudo com usuários de drogas injetáveis, denominado MANIF (franceses têm sempre nomes sonoros para as coisas), os usuários de drogas injetáveis daquele país morrem hoje, basicamente, em função da interação entre Aids e hepatite $\mathrm{C}$ crônica.

E o futuro? Bom, o futuro, sob este aspecto, é realmente mais promissor. Com um número menor de usuários de drogas injetando e/ou compartilhando equipamentos de injeção, temos menos pessoas sujeitas a estes riscos, ou seja, um menor número de pessoas "suscetíveis" (na linguagem da epidemiologia matemática) de se infectarem por esta via. Ao longo dos anos, portanto, teremos menos suscetíveis se tornando infectados, e, uma vez que os infectados são também potenciais fontes de novas infecções, um menor número de novas infecções geradas a partir desses casos potenciais. Em suma, teremos, mantidas as tendências atuais, uma espiral decrescente de novos casos de hepatite $\mathrm{C}$, em todos os países em que o controle de sangue tiver sua qualidade preservada ao longo do tempo, e houver um contingente decrescente de usuários de drogas injetáveis e/ou em que os usuários de drogas injetáveis praticarem, com menor freqüência, 
comportamentos que os coloquem em risco e/ou coloquem em risco seus pares.

Terminou? Bom, receio, mais uma vez, que ainda não. Temos de discutir agora a questão do uso de injeções não estéreis com finalidades médicas, o que soa bastante estranha para nós, brasileiros, urbanos, com menos do que, digamos, cinqüenta anos. Há muito, as farmácias e hospitais brasileiros utilizam, sistematicamente, ao menos no contexto urbano, seringas plásticas descartáveis na aplicação de injeções. Talvez haja exceções a essa regra de utilizar exclusivamente seringas descartáveis, que observei ao longo da minha prática como médico e da minha vida como cidadão e habitante da cidade do Rio de Janeiro, mas realmente não tenho conhecimento dessas possíveis exceções. A situação é bastante distinta, porém, em diversos países africanos e em alguns países do Leste europeu, como a Romênia, após o colapso do comunismo. Nesses países estão bem documentados surtos de HIV (até onde é do meu conhecimento, a transmissão do vírus da hepatite $C$ não foi ainda documentada com igual detalhe) em instituições de saúde devido à reutilização de seringas contaminadas na aplicação de medicamentos injetáveis.

Não resta dúvida hoje de que as injeções não estéreis com finalidade médica desempenharam um papel relevante na disseminação dos vírus da Aids e das hepatites $\mathrm{B}$ e $\mathrm{C}$ em diversos desses países. Tal questão vem sendo objeto de um esforço mundial, com a decisiva participação da Organização Mundial da Saúde (OMS), no sentido de reduzir, e, se possível, eliminar a transmissão desses vírus (e outros microorganismos) por seringas não-estéreis de uso médico. Além, é claro, do esforço paralelo de reduzir os riscos de transmissão associados ao uso injetável de substâncias de uso não-médico, como no caso dos usuários de 
drogas injetáveis. Enfim, também aqui, as perspectivas são promissoras, a médio e longo prazo, ainda que possam persistir bolsões de risco, como, por exemplo, nas guerras civis que vêm ocorrendo na África, em que as já precárias infra-estruturas de saúde se deterioram definitivamente, com a reversão dos parcos ganhos em termos de saúde pública obtidos até então.

Sumarizando toda esta seção, é possível afirmar que, mantidas as condições presentes, a epidemia de hepatite $C$ arrefecerá nas próximas décadas, cabendo, entretanto, saber a que custo em termos de vidas humanas isso ocorrerá, ou seja, as gerações futuras serão, sem dúvida, poupadas em parte desse problema, mas cabe cuidar e apoiar da melhor maneira possível as gerações presentes, entre as quais se incluem milhares de pessoas vivendo com a hepatite $\mathrm{C}$ crônica. $\mathrm{O}$ custo da nossa omissão seria incalculável, em termos de sofrimento e vidas humanas.

Uma alternativa, talvez definitiva, num prazo bastante dilatado, talvez venha a ocorrer a partir do desenvolvimento de uma vacina anti-hepatite $C$, nos moldes da hoje disponível (desde que haja recursos para adquiri-la, por parte dos sistemas públicos de saúde ou dos indivíduos/famílias) e efetiva vacina anti-hepatite B. Caso esta potencial vacina anti-hepatite $C$ venha a ser aplicada a todos os recém-nascidos, como vem ocorrendo com relação à vacinação anti-hepatite $\mathrm{B}$ em diversos países, obviamente, dotados de mais recursos e melhor infra-estrutura de saúde, vislumbraríamos um cenário bastante favorável no horizonte.

\section{Para não dizer que não falei . . . de}

\section{NÚMEROS . . E E DE ALGUMAS OUTRAS COISAS}

A despeito das imprecisões mencionadas anteriormente e exibidas na Figura 2 (ver pequeno quadro denominado "Número 
de países com dados não disponíveis"), os especialistas estimam que existam hoje no mundo 200 milhões de pessoas infectadas pelo vírus da hepatite C, ou seja, algo como 3\% da população mundial (os dados sistematizados na Figura 2 apontam para números mais baixos, mas se referem às informações sistematizadas pela OMS, em 1999. Infelizmente, não foi possível obter dados mundiais desagregados, revisados, referentes aos anos mais recentes).

Figura 2 - Dados da OMS referentes à hepatite $\mathrm{C}$ nas principais regiões do mundo - 1999

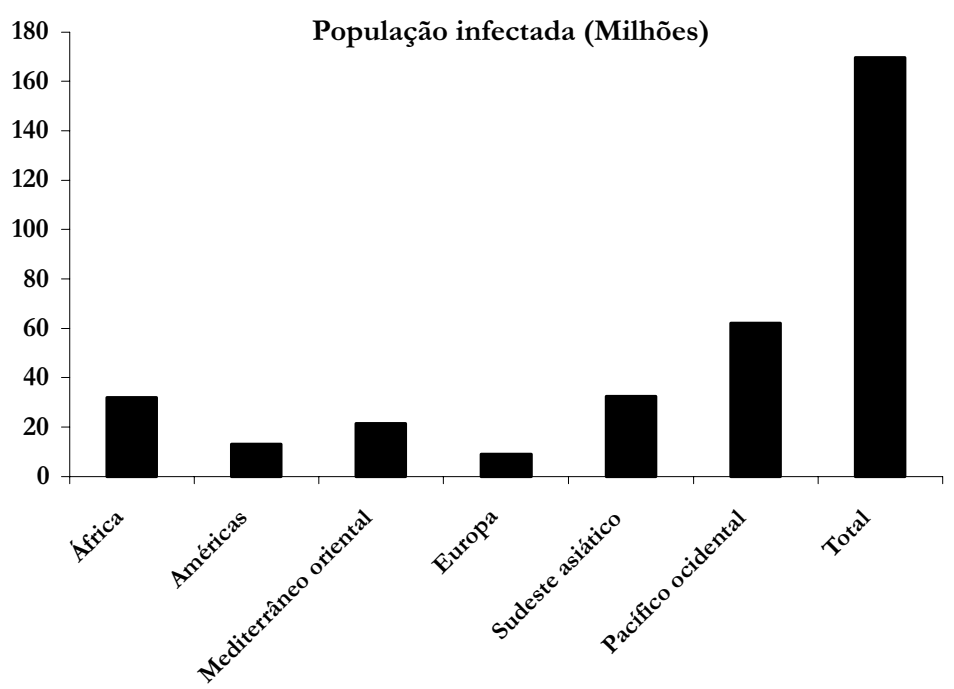



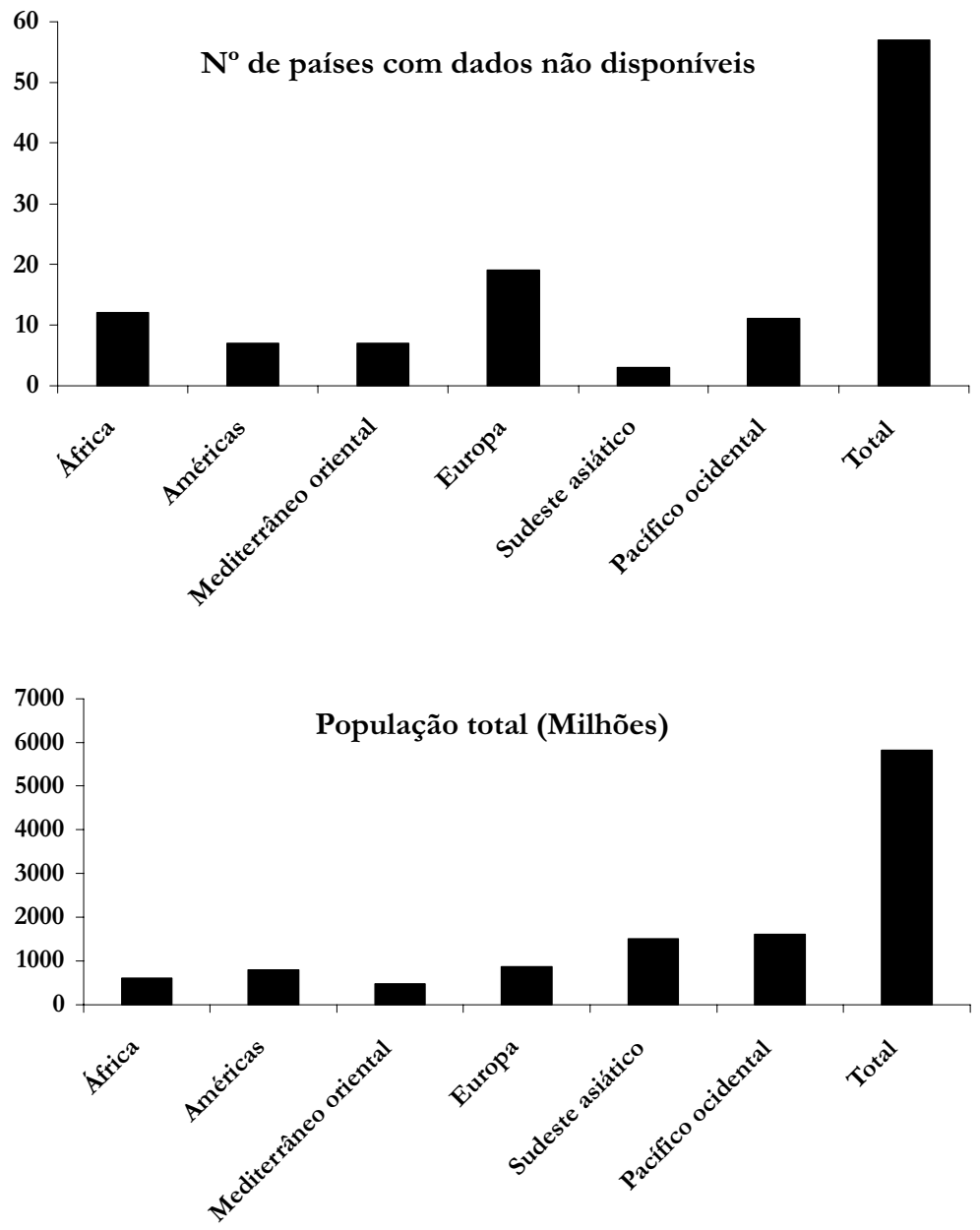


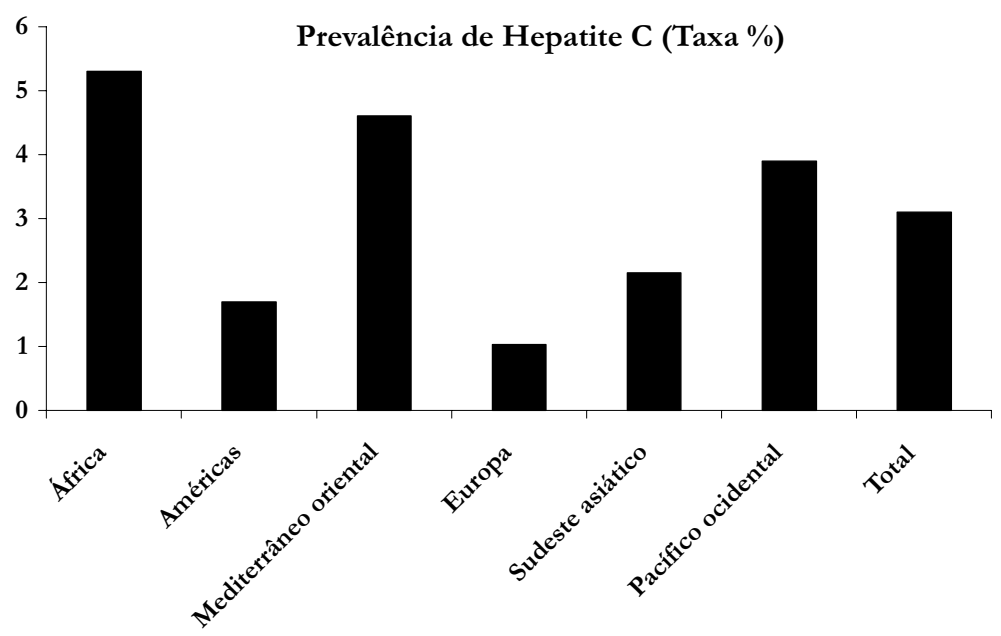

Região (OMS)

As estimativas de custos associados ao diagnóstico e tratamento, além das conseqüências para a produtividade de indivíduos, famílias e firmas, direta ou indiretamente, vinculadas à hepatite $C$, apenas nos Estados Unidos, atingem cifras astronômicas, da ordem de 54 bilhões de dólares. Parte desses custos está relacionada diretamente ao custo do tratamento, considerado extremamente dispendioso (20-30 mil dólares por paciente, por ano), mesmo para os padrões da sociedade mais rica do mundo.

As prevalências (medida de ocorrência da doença) da hepatite $\mathrm{C}$ em todo o mundo são absolutamente heterogêneas, entre as diferentes regiões, países e populações, por razões que não estão muito claras (Figura 2). Por exemplo, não se compreende ao certo porque populações isoladas, como as que vivem em 
certas localidades da região Amazônica, onde não são comuns procedimentos médico-cirúrgicos que utilizem transfusões e onde não há relatos de uso injetável de drogas, as prevalências possam ser relativamente elevadas (em torno de $6 \%$, cerca de dez vezes mais elevadas, por exemplo, do que na região Sul do Brasil). As explicações são diversas, tais como: o suposto papel de práticas rituais e da medicina tradicional, que envolvem contato com sangue (como escarificações), uma maior relevância em um dado contexto da transmissão sexual (devido à presença, por exemplo, de outras infecções sexualmente transmissíveis, atuando como possíveis cofatores), assim como variações referentes à composição étnica das populações, e a sua suscetibilidade maior ou menos ao vírus, influenciando, por exemplo, a capacidade de eliminar espontaneamente o VHC (ver discussão no capítulo 5). Enfim, quando há explicações em demasia, pouco harmônicas entre si, cabe desconfiar ou tentar combiná-las da melhor maneira possível.

Grosso modo, poderíamos subdividir o mundo em regiões de alta, média e baixa prevalência para o vírus da hepatite $C$ na assim denominada população geral, ou seja, entre os membros da população que não apresentem fatores de risco que os identifiquem como particularmente vulneráveis, como os usuários de drogas injetáveis. Em países de alta prevalência, como o Egito (o epicentro da epidemia na região que a OMS denomina Mediterrâneo Oriental; vide Figura 2), há localidades, especialmente nas áreas rurais, em que a prevalência pode chegar a 45$50 \%$, ou seja, metade da população está infectada pelo vírus da hepatite C. Estes achados contrastam dramaticamente com as prevalências baixíssimas (inferiores a $0,1 \%$ ) observadas nos países escandinavos. Situações de média gravidade têm sido veri- 
ficadas em países com grande contingente populacional (como China e Índia, que estão inseridas nas regiões que a OMS denomina, respectivamente, Pacífico Ocidental e Sudeste Asiático; vide Figura 2) e/ou grande área geográfica, como o Brasil, onde as prevalências variam bastante em função das regiões e populações específicas, como num mosaico de localidades com quadros epidemiológicos bastante distintos.

Aparentemente, as elevadíssimas prevalências verificadas nas áreas rurais do Egito se devem a uma desafortunada associação da hepatite C com uma segunda doença, a esquistossomose, freqüente naquele país, e que parece agravar o curso da hepatite C. Com o propósito de controlar a esquistossomose, tentou-se no Egito aplicar medicação injetável anti-esquistossomose em massa, o que teria sido feito com agulhas não estéreis. Enfim, ao que parece, não apenas não se resolveu a contento o problema da esquistossomose, como se criou, inadvertidamente, um segundo problema de saúde pública de grande magnitude “ a ampla disseminação da hepatite C. Parece uma dessas questões em que o homem tenta manipular a ecologia de uma ou mais doenças sem atentar para os efeitos colaterais das suas ações, e acaba por gerar uma catástrofe, nos moldes dos mais desastrados "aprendizes de feiticeiro", metáfora popular presente nas mais diversas culturas (pois deve haver muitos deles, fazendo bobagens mundo afora), imortalizada na poesia de Goethe (patrono das letras alemãs) e no filme Fantasia, de Walt Disney, numa atuação fascinante de Mickey Mouse.

\section{UMA EPIDEMIOLOGIA A SER (RE) CONSTRUÍdA}

Persistem, no campo da epidemiologia da hepatite C, inúmeras dúvidas, que deverão ser exploradas por estudos futuros. 
Algumas dessas dúvidas já foram mencionadas ao longo deste texto, como a necessidade de contar com estimativas mais acuradas quanto à prevalência da hepatite $\mathrm{C}$ nos diferentes países, especialmente naqueles mais extensos e/ou populosos, com assimetrias regionais marcantes, além de diversos países africanos e do Leste europeu (Figura 2). Se, por um lado, a qualidade das informações aumentou substancialmente nos países do Leste europeu, pós-colapso do comunismo; por outro, parece não ter havido progresso (e, ao que tudo indica, haveria mesmo deterioração adicional da qualidade das informações, na presente década, em diversos países africanos, às voltas com graves crises de abastecimento de alimentos e guerras civis). Portanto, uma Figura 2 devidamente atualizada para o ano de 2007 apontaria para um quadro substancialmente melhor na Europa (leia-se, Leste europeu) e, provavelmente, ainda pior na África.

Abrindo aqui um parêntese para o Brasil, constatamos que, a despeito de se tratar de uma doença infecciosa de notificação compulsória (vide informações em $<\underline{\text { http://portal.saude.gov.br/ }}$ portal/aplicacoes/anuario2001/morb/notas.cfm>), sob o código B17.1, da Classificação Internacional de Doenças (CID10), da OMS, as informações sobre a hepatite $C$ em nosso país são bastante fragmentárias, quando não, indisponíveis. Publicações de referência, como, por exemplo, a compilação de dados da Fundação Instituto de Geografia e Estatística do Brasil (IBGE), denominada Brasil em Números, não contêm informações atualizadas sobre a hepatite $\mathrm{C}$ no território nacional.

Uma segunda dúvida, já mencionada, é o papel específico (ainda que relativamente pouco importante, frente à transmissão sangüínea) da transmissão sexual na dinâmica da epidemia de hepatite C. Outras áreas de incerteza se prendem aos fatores que fazem com 
que determinados pacientes evoluam melhor ou pior, mais ou menos rapidamente, e mesmo eliminem definitivamente os vírus. $\mathrm{Na}$ ausência de critérios claros, os modelos matemáticos que buscam predizer os cenários futuros da epidemia no mundo partem do pressuposto de uma evolução padrão entre os pacientes, o que não deixa de ser uma simplificação grosseira da diversidade da evolução real da infecção, documentada pela pesquisa biológica e clínica.

Controvérsias acirradas persistem com relação aos riscos associados a outros comportamentos e práticas, como a tatuagem, a acupuntura e o compartilhamento de canudos utilizados na aspiração da cocaína em pó. O sangramento da mucosa nasal de pessoas que aspiram cocaína, especialmente de drogas misturadas (habitualmente denominadas "malhadas" ou "batizadas" pelos seus consumidores), é relatado com muita freqüência pelos usuários de drogas, em função das propriedades vasoconstritoras (de contração da parede dos vasos) da cocaína, que alteram o fluxo sangüíneo local, com episódios de constrição, seguidos de dilatação, além dos efeitos adicionais de vários contaminantes, vários deles lesivos para a mucosa nasal, como o pó de vidro ou o pó de gesso. Até que ponto os canudos contendo restos de sangue de um indivíduo, emprestados a um segundo indivíduo são, de fato, capazes de transmitir o VHC não se sabe ao certo.

Quanto à acupuntura, nem mesmo os próprios chineses, pais da matéria, se entendem com relação à eventual transmissão ou não do VHC por esta via. Com relação às tatuagens, a absoluta diversidade dos contextos (mais ou menos higiênicos ou mesmo nada higiênicos) em que elas são feitas e a importante superposição com práticas e contextos de risco, como entre usuários de drogas e no ambiente prisional, tornam a questão, no mínimo, espinhosa, ou talvez 'agulhosa', se me permitem o neologismo. 
Áreas adicionais de incerteza dizem respeito à transmissão do VHC no contexto das intervenções cirúrgicas de pequeno e médio porte em odontologia, realizadas em consultórios (e não em centros cirúrgicos, pois, neste caso, tais intervenções seguem a lógica do risco e das respectivas medidas de proteção utilizadas nas demais intervenções cirúrgicas), e com relação à transmissão da mãe para o bebê (ou transmissão vertical). Com relação às primeiras, há razoável consenso quanto à saliva conter partículas virais do $\mathrm{VHC}$, mas não em número suficiente, e sem viabilidade (vigor) biológica. Portanto, neste caso, a eventual transmissão teria de ser secundária à contaminação da saliva pelo sangue.

Com relação à transmissão vertical, existe hoje um razoável consenso quanto a esta transmissão existir de fato, embora com taxas bastante mais baixas em comparação com a transmissão mãe-bebê entre mulheres infectadas pelo HIV que não receberam a devida profilaxia (intervenção preventiva). Não há concordância por ora quantos aos riscos de amamentar, mas sabese que a co-infecção pelos vírus da hepatite $\mathrm{C}$ e da Aids aumenta as chances do bebê se infectar com o vírus da hepatite.

Reproduzo a seguir um quadro dos principais fatores de risco para a hepatite C, segundo um site de ampla consulta nos Estados Unidos (Quadro 1). Como o leitor pode observar, as formulações do referido site são bastante mais assertivas do que o meu texto, de cauteloso epidemiologista, sempre às voltas com dúvidas metodológicas, quanto aos riscos associados, por exemplo, ao compartilhamento de canudos ou à feitura de tatuagens. Enfim, como dizem que: "cautela e caldo de galinha não fazem mal a ninguém" (certamente, não consultaram as galinhas quanto à segunda afirmação), é melhor evitar os fatores de risco que, potencialmente, podem estar associados à transmissão do vírus da hepatite $\mathrm{C}$. 
Quadro 1 - Fatores de risco para hepatite C

\section{Os principais meios através dos quais a hepatite $\mathbf{C}$ se dissemina:}

- Compartilhando seringas e agulhas (e outros equipamentos de injeção) para o uso de drogas injetáveis

- Transfusões de sangue anteriores a 1992

- Equipamento médico contaminado (por exemplo, máquinas de diálise renal)

- Acidentes com objetos pérfuro-cortantes, como agulhas

- Tatuagem e piercing com agulhas ou tinta contaminada

- Sexo desprotegido

- Compartilhamento de canudos para aspiração de cocaína

- Compartilhamento de itens pessoais que podem estar associados a sangramento (como lâminas de barbear e escovas de dente)

\section{Você NÃO pode pegar hepatite $\mathrm{C}$ :}

- Abraçando

- Cumprimentando alguém (aperto de mão)

- Tendo alguém espirrado em cima de você

- Tendo alguém tossido em cima de você

- Compartilhando talheres, louça ou copos

- Beijando*

- Através de qualquer contato físico, eventual, não-íntimo

- Outros contatos físicos sem troca de sangue

Fonte: adaptado de http://www.all-about-hepatitisc.com/readytolearn/about/ what_is/spread.jsp

* No original, menciona-se exclusivamente o beijo no rosto, o que me parece uma cautela levada a extremos, já que a literatura especializada internacional (após busca exaustiva) não documenta casos inequívocos de transmissão por beijos de qualquer natureza. 
Com todas essas incertezas em mente, despeço-me do leitor, rumo ao próximo capítulo. E quem disse que a ciência consegue aplacar nossas angústias e responder sempre às nossas dúvidas? 


\section{I Por Mares nunca Dantes navegados}

As novas perspectivas da pesquisa e tratamento em hepatite C são realmente promissoras, ainda que se observe um franco descompasso entre o imenso montante de recursos investidos no campo da Aids (com a qual a hepatite pode ser, grosso modo, comparada em termos de duas epidemias de grande magnitude e abrangência; vide capítulo 1) à área bastante mais pobre e menos visível da hepatite $\mathrm{C}$.

Em ambos os casos, da Aids e da hepatite C, lidamos com doenças causadas por vírus, agentes infecciosos que lançam mão da infra-estrutura e economia do organismo por eles parasitados em consonância, literal, com o preceito bíblico: crescei e multiplicai-vos!

Antes de tudo, cabe refletir: o único meio de derrotar um inimigo poderoso é conhecer, em detalhe, seus pontos fortes e fracos! Portanto, é necessário conhecer nossos hóspedes indesejáveis, como os vírus da hepatite $\mathrm{C}$ e da Aids, em todo o detalhe possível.

Um segundo eixo que estrutura a lógica da pesquisa nessa área é buscar dissimilaridades entre aquilo que se combate e aquele que empreende o combate, ou seja, de um ponto de vista de nós " seres humanos " dissimilaridades entre eu (humano) e nãoeu (vírus). A razão subjacente a este segundo eixo é tentar preservar a saúde do paciente enquanto se move o ataque ao vírus. Portanto, nesse sentido há de se encontrar substâncias que inter- 
firam na reprodução dos vírus, mas não interfiram no metabolismo dos seres humanos. As chances para tal não são muitas, uma vez que os vírus são seres de estrutura absolutamente econômica e precisa, além de extremamente flexíveis e dinâmicos. Portanto, não há muitos flancos a serem atacados.

Os alvos quase exclusivos de um possível ataque são os 'entroncamentos' centrais da reprodução viral (operação análoga a um ataque hipotético a instalações elétricas ou hidráulicas de uma base inimiga; com o devido perdão do recurso a esta nova metáfora bélica), que são invariavelmente regulados (entre outros compostos químicos, como ocorre em todos os demais seres vivos) por aceleradores (catalisadores) de reações bioquímicas, denominados enzimas. Assim como na pesquisa em HIV/Aids e outras viroses, cabe encontrar substâncias que bloqueiem esses entroncamentos essenciais no maior número possível de pontos, atacando, se possível, muitas, e, melhor ainda, todas as enzimas essenciais à reprodução viral. Para isso, é necessário conhecer em detalhe a estrutura e a dinâmica de cada um desses entroncamentos, tarefa realmente desafiadora, seja do ponto de vista da sua estrutura, seja da perspectiva da sua operação.

Finalmente, seguindo o raciocínio do pesquisador sinoamericano da área de HIV/Aids, David Ho, é preciso atacar os diferentes pontos fracos de forma simultânea, de modo a dar poucas chances ao adversário de resistir aos ataques por meio de transformações na sua própria estrutura, através da sua 'reconfiguração’ genética, através das assim denominadas mutações, transformações comuns a todos os vírus (e demais seres vivos, ainda que os demais entes biológicos estejam muito longe da flexibilidade dos vírus). 
Se utilizarmos a metáfora de uma luta de boxe, seria o caso de não apenas levar o adversário às cordas, mas seguir golpeando, em diversos pontos do seu corpo, até que ele perca definitivamente o combate. A grande diferença aqui entre vírus e boxeadores é que enquanto espécie (conjunto de indivíduos) os vírus são, num sentido prático, imortais, enquanto os campeões de boxe são imortais apenas na memória dos fãs deste esporte (entre os quais, não me incluo). Portanto, o máximo que é possível conseguir é retirá-los de cena por um tempo, tempo esse que, espera-se, seja bastante longo, tendendo mesmo ao infinito. Até que ponto esse sumiço prolongado dos nossos incômodos visitantes pode se transformar em desaparecimento permanente é uma questão em aberto, dependente da natureza dos visitantes (os vírus), dos seus anfitriões (nós) e do quanto conseguimos infernizá-los quando da sua visita inesperada e, geralmente (em se tratando de vírus patogênicos), indesejada e incômoda.

Cabe aqui a ressalva de que a imensa maioria dos vírus não é patogênica para os seres humanos (ou seja, não nos causam mal algum). Como mostram os biólogos que não estão envolvidos em pesquisa biomédica, mas que lidam cotidianamente com uma visão mais ampla da natureza, desenvolvendo estudos propriamente ecológicos, temos da biologia uma visão absolutamente antropocêntrica, valorizando, ainda que para maldizê-los e combatê-los, os vírus (e outros microorganismos) que afetam a nossa saúde. De fato, a grande maioria dos vírus afeta plantas, bactérias (os assim denominados, bacteriófagos) e outros animais, passando ao largo dos seres humanos. Portanto, o que descrevemos aqui se limita a um subconjunto reduzido de vírus patogênicos para os seres humanos, em particular, o vírus da hepatite C. 
Certamente ocorrerá ao leitor, a pretexto dos vírus patogênicos para o ser humano, a lembrança de visitantes humanos indesejáveis, a perturbar a paz da sua casa ou trabalho, e, cabe lembrar, que esse visitantes humanos indesejáveis contam-se habitualmente nos dedos das mãos. $\mathrm{O}$ que não incomodam visitantes virais, que nos chegam em massa, em números da ordem de centenas de milhares e mesmo milhões! Dá até saudades dos incômodos visitantes humanos..

As novas terapias que se desenham no horizonte da hepatite $C$ seguem exatamente os três eixos mencionados: pesquisa de ponta com relação à dinâmica viral, tentando identificar diferentes drogas que possam atacar os pontos fracos previamente identificados no ciclo reprodutivo dos vírus, com o desenvolvimento de novos medicamentos, drogas estas, na medida do possível, letais para os vírus e inócuas (ou, ao menos, pouco agressivas) para o organismo humano.

As principais linhas seguidas na busca de novas alternativas de tratamento são:

1) $O$ desenvolvimento de medicamentos que bloqueiem as enzimas virais protease, polimerase e helicase - ainda não se conhece precisamente o papel da enzima protease no ciclo reprodutivo do VHC, inclusive porque a definição precisa de sua estrutura (através de uma técnica denominada cristalização) é bastante recente. Sabe-se, com segurança, que a protease participa ativamente da clivagem (quebra) de polipeptídeos (cadeias de aminoácidos, constituintes básicos das proteínas) com papel vital na estrutura dos vírus, passo, portanto, essencial à reprodução dos vírus. Bloqueada a protease, o ciclo reprodutivo do VHC não se completa e a infecção não prossegue. No exato momento em que redijo este capítulo estão em fase avançada de testes drogas inibi- 
doras da protease do VHC. Neste momento, estão também em desenvolvimento e avaliação clínica inibidores de uma segunda enzima viral, a polimerase. Esta última enzima catalisa (acelera) a replicação de um dos elementos-chave de guarda e transmissão de informações biológicas e operacionalização da síntese das proteínas "o RNA (sigla inglesa para ácido ribonucléico).

Finalmente, a terceira enzima que seria um alvo potencial de medicamentos bloqueadores, a helicase, favorece o processo de ‘desenovelamento' do genoma do vírus, uma vez que a estrutura que contém as informações biológicas, que no caso do vírus da hepatite C é o RNA, está toda enovelada na estrutura central do vírus e é preciso desenovelá-la de modo a prosseguir com o ciclo reprodutivo do vírus. Ou seja, a enzima auxilia o processo de separar e esticar os fios enovelados de RNA, embaralhados como se um gato estivesse brincando com um novelo de lã (quem já teve gatos sabe a barafunda que eles podem provocar em um fio mais ou menos longo, e os fios de DNA e RNA são, habitualmente, bastante longos). Até onde pude averiguar, não existem no momento inibidores da helicase em fase de avaliação clínica (estudos em seres humanos).

2) A produção de novas variedades de interferon (substância mencionada no capítulo 3), mais eficientes no combate ao VHC e menos tóxicas para os seres humanos (pois, como discutido no mesmo capítulo, uma das limitações das terapias hoje disponíveis é justamente a toxicidade das modalidades de interferon hoje empregadas na terapia da hepatite C).

3) O desenvolvimento de drogas imunomodeladoras, ou seja, drogas que modulem a resposta imune dos pacientes, no senti- 
do de que eles lancem mão de suas próprias defesas orgânicas de uma forma mais efetiva e sejam capazes de eliminar os vírus ou, ao menos, manter a infecção sob controle, detendo a progressão clínica da doença.

4) a 'blindagem' do fígado através da transferência para este órgão de propriedades genéticas/bioquímicas que ele não possui naturalmente ou possui em quantidade e intensidade insuficientes para fazer face à hepatite C. Neste caso, tentar-se-ia transferir para o fígado genes capazes de induzir e coordenar a síntese do próprio interferon e/ou de outros compostos presentes na resposta imune do organismo ao VHC e outros vírus e microorganismos, como, por exemplo, as citocinas.

5) O desenvolvimento de agentes antifibróticos, ou seja, drogas que não interfeririam propriamente na evolução da infecção, mas sim nos seus desdobramentos (discutidos no capítulo 2), de desorganização da estrutura do fígado, com perda da sua arquitetura natural (dita também 'funcional', ou seja, que funciona em sintonia com o metabolismo geral do organismo, produzindo substâncias úteis, filtrando substâncias tóxicas etc.).

Estas substâncias não eliminariam, portanto, os vírus do organismo, assim como não alterariam o curso da infecção, mas evitariam conseqüências graves da agressão continuada que a infecção e eventos correlatos (como discutido no capítulo 2) determinam na estrutura do fígado, podendo evoluir para um quadro em que boa parte do órgão esteja tomado por tecido não funcional, fibrótico, o que, clinicamente, corresponde a um quadro de cirrose hepática. 
6) O desenvolvimento de vacinas terapêuticas/anticorpos neutralizantes, o que discutirei a seguir, no contexto das vacinas para a hepatite $C$ de um modo geral.

Obviamente, o melhor remédio é, também aqui, prevenir, como diz o adágio popular. Neste âmbito temos iniciativas de cunho biomédico (como as vacinas), mas também diversos esforços no sentido de aprimorar as iniciativas de prevenção em curso no momento. Uma iniciativa bastante enfatizada pela pesquisa contemporânea em uso indevido de drogas e danos e riscos a ele associados é o desenvolvimento de novas estratégias de prevenção da transição do consumo de drogas para o uso de drogas injetáveis. Como vimos no capítulo anterior, a infecção pelo vírus da hepatite $\mathrm{C}$ ocorre, o mais das vezes, de forma muito precoce entre usuários de drogas injetáveis. Portanto, a melhor forma de prevenir novas infecções é evitar que usuários de drogas por outras vias venham a injetá-las. As alternativas em curso combinam apoio psicossocial, aconselhamento, psicoterapia e iniciativas que mobilizam os pares mais experientes no sentido de reforçar nos usuários novatos a idéia de evitar práticas mais danosas e/ou arriscadas. Mais recentemente, tem-se tentado reduzir a 'fissura' (em inglês, craving) por drogas estimulantes por meio de medicação específica (isso, sem abrir mão das demais alternativas), acredita-se que, reduzindo a fissura, é possível reduzir a demanda por formas de uso com efeitos mais imediatos e potentes, como é o caso do uso injetável da cocaína e da anfetamina e do uso do crack fumado.

Visto isto, vamos, então, às futuras vacinas anti-VHC.

Como todo vírus RNA (uma comparação que vem à mente de imediato é, novamente, do vírus da hepatite $\mathrm{C}$ com o seu 
primo famoso, o vírus da Aids), o vírus da hepatite C é especialmente mutável. Mutações são alterações do patrimônio genético, inerentes ao ciclo reprodutivo e transmissão de informações genéticas de quaisquer organismos, e que representam, a princípio, um risco para organismos com estrutura complexa, como nós, seres humanos. Óbvio que nós, humanos, sofremos mutações nas nossas estruturas de guarda de informações (no nosso caso, primariamente, o DNA, sigla inglesa para ácido desoxirribonucléico), caso contrário estaríamos na contramão da teoria mais abrangente da biologia, que é a Teoria da Evolução.

Mas por sermos biologicamente complexos, desenvolvemos, ao longo de centenas de milhares de anos, diversos mecanismos de correção de eventuais mutações. Já os vírus 'apostaram suas fichas na roleta' da evolução, no seu caráter de extrema simplicidade, flexibilidade e dinamismo e, portanto, enquanto população (e devem ser sempre pensados enquanto populações, e não enquanto indivíduos, como vastos aglomerados de indivíduos, pois só agem 'em bandos'). Portanto, para eles, mutações podem ser uma estratégia bastante benéfica de autotransformação e adaptação a condições inicialmente adversas, e isso se dá em prazos curtíssimos, numa velocidade inimaginável para nós, seres humanos. Por essa razão, os vírus não investem muito (ou mesmo nada) em mecanismos de correção de mutações, simplesmente 'mutam'/mudam e pronto!

O organismo, às voltas com uma invasão desses 'ariscos' parasitas, é que tem de 'se virar' para acompanhar a estonteante velocidade de transformação dos vírus, que materializam o famoso verso de Raul Seixas: "eu prefiro ser essa metamorfose ambulante" (não ficando claro se a letra de Raul Seixas é autobiográfica ou uma homenagem velada aos vírus). Poderíamos di- 
zer que, em se tratando desses seguidores fiéis de Raul Seixas, o organismo infectado está sempre 'correndo atrás do prejuízo', tentando identificar em que direção se metamorfosearam os seus invasores, enfim, em que coisa, afinal, eles se transformaram. Como isso se dá numa velocidade e com uma diversidade imensas, é freqüente que o organismo parasitado perca o pulso dos acontecimentos e não consiga mais seguir seus velozes invasores. Com isso, a infecção prossegue, e o quadro clínico eventualmente se agrava.

Para ajudar o organismo a seguir reconhecendo quem são seus invasores e para que ele continue a se defender contra eles ('vacinas terapêuticas') ou os reconheça de antemão e não os deixe invadi-lo e se instalar confortavelmente, como se a casa do organismo deles fosse ('vacinas profiláticas'), é preciso lançar mão de recursos artificiais: as vacinas. Cabe observar, no entanto, que as vacinas não 'inventam' nada, mas aperfeiçoam ou modificam recursos que já existem na natureza, só que habilmente driblados pelos 'sagazes' vírus (tudo num sentido figurado, pois, obviamente, vírus não são seres conscientes, muito longe disso, e vacinas são produtos biológicos e não estrategistas).

Explicando com maior detalhe, as vacinas profiláticas induzem, caso sejam de fato protetoras, algo que é denominado "imunidade estéril", ou, trocando em miúdos, uma defesa (imunidade) em que não está presente uma dada infecção (em relação a qual o organismo se mostra estéril, ou seja, não infectado). Já as vacinas terapêuticas não impediriam a infecção propriamente dita, mas impediriam ou minimizariam sua progressão, fazendo com que a infecção não evolua para uma infecção disseminada, que se traduziria, clinicamente, em quadros graves de doença e mesmo o óbito do organismo infectado. 
No caso da hepatite C, assim como no da Aids, estão em pauta ambas as possibilidades de desenvolvimento de vacinas, profilática e terapêutica, decisão a meu ver bastante acertada, uma vez que há urgência em abortar ambas as epidemias, de grande magnitude e gravidade, e, como diz o ditado, é melhor um pássaro na mão (vacina terapêutica) do que dois (ou antes, um superpássaro, a tão desejada vacina profilática) voando!

As perspectivas de uma vacina para a hepatite $C$ são hoje algo ainda distante, não havendo, mesmo entre os mais otimistas, quem acredite em uma vacina disponível no mercado nos próximos dez anos.

Há bastante debate sobre qual estratégia seria a mais indicada para induzir uma imunidade realmente efetiva e duradoura contra o VHC. Não entrarei aqui em detalhes, que fogem ao propósito do livro e ultrapassam a competência do seu autor. Brevemente, pode-se dizer que as pesquisas apostam em duas direções, possivelmente complementares: a proteção a ser induzida por anticorpos (ditos neutralizantes, ou seja, que neutralizam a agressão; grosseiramente, nos moldes como um antiácido neutraliza o suco gástrico e diminui a azia, com a diferença fundamental, que esta última reação é estritamente química, e não bioquímica, como a primeira) e a proteção conferida por determinadas células de destruição e/ou memória. Estas células, denominadas linfócitos, reconhecem as características dos agentes agressores, destruindo-os e/ou coordenando a sua destruição, ao convocarem para a briga seus piores desafetos (outras estruturas e produtos com ação viricida, ou seja, destruidores de vírus). O termo memória se refere aqui à propriedade de algumas dessas células guardarem informações ao longo do tempo sobre quem são, como são e como se comportam os nossos even- 
tuais agressores, à maneira das delegacias de polícia, que 'ficham' criminosos (nossa sobrevivência está garantida, antes de tudo, pelo fato de que nossas células de memória são bastante mais eficientes que as nossas delegacias. Caso contrário, teríamos uma hecatombe, não apenas devido à violência urbana, o que infelizmente já ocorre, mas devido a toda sorte de vírus e outros microorganismos).

No momento, estão em teste vacinas anti-VHC em chimpanzés. Até onde é do meu conhecimento, não há, por ora, vacinas anti-VHC, profiláticas ou terapêuticas, sendo testadas em humanos. As perspectivas mais promissoras parecem ser derivadas da resposta imune que, naturalmente, um grupo de pessoas estabelece contra a infecção pelo VHC, conseguindo eliminar o vírus do seu organismo. Portanto, haveria que "imitar" o engenho e a arte da própria natureza, estudando em detalhe como tais pessoas conseguem eliminar os vírus, e transferir essas armas para aqueles que, naturalmente, não são capazes de fazê-lo, ou seja, o grupo de pessoas nas quais a infecção progride e pode se tornar eventualmente grave.

Aliás, não poderia encerrar esse capítulo sem uma mensagem antibélica, eu que usei e abusei de metáforas militares e policiais em dois capítulos deste pequeno livro. Não resta dúvida de que, num prazo curtíssimo, não resta a nós, seres humanos, outra opção que não seja partir para a luta contra os vírus da hepatite C, pois afinal, podem estar em risco nossas vidas, enquanto indivíduos e mesmo enquanto espécie. Emergências à parte, no entanto, tais combates de vida e morte se mostram, a longo prazo, não só grosseiros, como contraproducentes. A estratégia adequada é, ao contrário, conviver diplomaticamente com nossos antigos desafetos, convidando-os para partilhar conosco 
das benesses da natureza. Portanto, a médio e longo prazo, é muito pouco provável que venhamos a eliminar o VHC e outros agentes biológicos da face da terra (o que, muito freqüentemente, gera efeitos devastadores sobre a ecologia), mas, antes, venhamos a desenvolver métodos de lidar com eles; por exemplo, favorecendo a disseminação de suas variantes menos agressivas (sugestão cara ao biólogo evolucionista norte-americano, Paul Ewald), e/ou mantendo sob vigilância estrita e eventual controle suas agressões potenciais, como fazemos com irmãos briguentos.

Afinal, como mostra o escritor argentino Jorge Luis Borges, anteriormente citado, no belíssimo poema "Milonga de dois irmãos", a história do mundo ficou definitivamente marcada pelo assassinato de Abel por parte do seu irmão Caim (a "marca humana", segundo os velhos sábios hebreus). Como diz o poema, através dos tempos, das guerras e dos crimes, Caim segue matando Abel, e estes assassinatos são, antes de tudo, a nossa triste crônica enquanto humanos vivendo em sociedade.

Não resta dúvida de que os vírus são irmãos especialmente pirracentos, mas vieram para ficar, e nada como a diplomacia.. 


\section{Notas Finais: 0 Som do Silêncio}

A recentemente falecida ensaísta norte-americana Susan Sontag, ao discutir seu próprio processo de adoecimento, menciona que somos, todos nós, habitantes involuntários de um segundo país (sendo o primeiro, o país ensolarado da saúde), do qual ninguém quer ser cidadão, país, que, metaforicamente, congregaria as várias doenças e males que afligem os seres humanos. Tomando o seu exemplo de luta contra a adversidade (Sontag padeceu de um câncer de mama e complicações daí advindas, por três décadas), cabe retomar sua opção de trazer à luz o sofrimento, de modo a enfrentá-lo face a face e superá-lo, na medida do possível. Seus ensaios sobre as metáforas destrutivas que gravitam em torno de diferentes doenças, como a tuberculose, o câncer e a Aids, me inspiraram a escrever, em ponto menor, algo sobre uma outra forma de fazer com que a doença transite sem obstáculo por esse país de sombras “ dar voz ao silêncio.

A idéia dos compositores pop Art Garfunkel e Paul Simon de batizar uma de suas músicas de "O som do silêncio" me parece lapidar nesse sentido. Vamos aos seus primeiros versos, em tradução literal: Alô escuridão, minha velha amiga / Vim para conversar de novo contigo / Porque uma visão rastejando suavemente / Deixou suas sementes enquanto eu dormia / E esta visão que se plantou no meu cérebro / Ainda permanece / Encerrada no som do silêncio (no original: "Hello darkness, my 
old friend / I've come to talk with you again / Because a vision softly creeping / Left its seeds while I was sleeping / And the vision that was planted in my brain / Still remains / Within the sound of silence").

O propósito deste livro foi dialogar com os sons do silêncio que cercam a epidemia da hepatite $\mathrm{C}$, que, por razões que tentei esboçar, não vêm sendo objeto de uma discussão aberta no âmbito da sociedade, como no caso da Aids, por mais dolorosa e difícil que tenha sido esta última. Se ele puder chamar a atenção de um punhado de eventuais leitores, para além dos profissionais que lidam no seu dia-a-dia com os pacientes vivendo com a hepatite $\mathrm{C}$, terá valido a pena escrevê-lo.

A palavra final, obviamente, é daqueles que convivem diariamente com a infecção e/ou com a doença, que, mais do que ninguém, sabem como é fundamental falar abertamente sobre o tema, mobilizar a sociedade e os meios de comunicação.

Disse Dante que o amor move o sol e as estrelas. Junte-se a isto, o esforço e o cálculo, e teremos o motor da ciência. Nem mesmo Descartes era de todo cartesiano... Não se faz ciência biomédica sem compaixão e solidariedade. 


\section{Sugestões DE LEITURAS}

$\mathbf{N a}$ área de biologia, cabe citar o excelente capítulo "Terapias celulares e bioengenharia tecidual", de Radovan Borojevic e Alex Balduíno, na obra coletiva Genômica (São Paulo: Atheneu, 2005), organizada por Luís Mir.

O livro mais criativo de imunologia para leigos de que tenho notícia é Tending Adam's Garden ("Zelando pelo Jardim de Adão"; editado em Amsterdã, pela Academic Press, 2004), do imunologista e filósofo da ciência norte-americano, naturalizado israelense, Irun Cohen, infelizmente, ainda não traduzido para o português.

$\mathrm{Na}$ desafiadora interface entre a física e biologia, mencionei o trabalho de Mark Haw, Middle World: the restless heart of matter and life (Nova York: Macmillan, 2006), que me chamou a atenção por dar a (falsa?) impressão de se tratar de um livro de aventuras (quem sabe, de aventuras das moléculas), nos moldes da outra Terra Média, a de Tolkien, no Senhor dos Anéis. O texto de Feynman citado está em seu segundo livro de (também) curiosas aventuras (e que, por isso mesmo, tem o subtítulo de: Further adventures of a curious character), que tem por título: What do You Care what other People Think? (Nova York/Londres: Norton \& Company, 1988).

Referi, en passant, os trabalhos de Paul Ewald. Cabe citar o clássico Evolution of Infectious Diseases (Oxford: Oxford University Press, 1996) e o excessivamente especulativo (a meu ver) Plague 
Time: the new germ theory of disease (Nova York: Anchor Books, 2002).

$\mathrm{Na}$ área clínica, lancei mão da antologia Hepatite $C$ : aspectos críticos de uma epidemia silenciosa (Rio de Janeiro: Ed. Fiocruz, 2005), além de revisões atualizadas permanentemente na base de dados Medline (http://www.ncbi.nlm.nih.gov/entrez/ query.fcgi? $\mathrm{DB}=$ pubmed).

A despeito de estar desatualizado, problema relevante numa área especialmente dinâmica e polêmica, o livro de Crofts, $\mathrm{N}$; Thompson, S \& Kaldor, J. Epidemiology of the Hepatitis C Virus, editado pelo Communicable Diseases Network, Austrália/Nova Zelândia, em 1999, ainda constitui uma excelente síntese da epidemiologia da hepatite $C$ no mundo. As informações posteriores a esta data foram obtidas a partir da revisão de inúmeros trabalhos, que busquei no banco de dados Medline.

Os livros de Susan Sontag sobre as doenças e suas metáforas estão traduzidos para o português, com os títulos de Doença como Metáfora (Rio de Janeiro: Paz \& Terra, 2005) e Aids e suas Metáforas (São Paulo Companhia das Letras, 1989). Recentemente, publicou-se, em português, nova obra da autora sobre o sofrimento e a empatia - Diante da Dor dos Outros (São Paulo: Companhia das Letras, 2003).

Os versos de Carlos Nejar foram extraídos de sua Obra Completa (Rio de Janeiro: Nova Fronteira, 1980). A tradução de Haroldo de Campos do Gênesis consta de Bereshit: a cena de origem (São Paulo: Perspectiva, 2000). Citei ainda outros trechos da Bíblia, a partir do site <www.bibliaonline.net/?lang=BR>. Da mesma forma, as letras de música foram verificadas na Internet, nos sites dos respectivos compositores e letristas. 
Citei as Flores do Mal, de Charles Baudelaire, a partir da edição bilíngüe organizada e traduzida por Ivan Junqueira (Rio de Janeiro: Nova Fronteira, 1985). Os versos de Carlos Drummond de Andrade estão na sua Poesia Completa (Rio de Janeiro: Aguilar, 2002). Os versos de John Donne, e de outros poetas ingleses metafísicos, estão em The Major Metaphysical Poets of the Seventeenth Century (Nova York: Washington Square Press, 1969). O poema e o conto de Jorge Luis Borges a que faço alusão, ao longo do texto, estão em suas Obras Completas (Buenos Aires: Emecé,1974) 
Formato: $12,5 \times 18 \mathrm{~cm}$

Tipologia: Letter Gothic e Garamond

Papel: Pólen Bold $70 \mathrm{~g} / \mathrm{m}^{2}$ (miolo)

Cartão Supremo $250 \mathrm{~g} / \mathrm{m}^{2}$ (capa)

Fotolitos: Laser vegetal (miolo)

Engenho e Arte Editoração Gráfica Ltda. (capa)

Impressão e acabamento: Imprinta Express Ltda.

Rio de Janeiro, julho de 2006

Não encontrando nossos títulos em livrarias, contactar a EDITORA FIOCRUZ:

Av. Brasil, 4036 - térreo - sala 112 - Manguinhos

21040-361 - Rio de Janeiro - RJ

Tel.: (21) 3882-9039 e 3882-9041

Telefax: (21) 3882-9006

http://www.fiocruz.br/editora

e-mail: editora@fiocruz.br 

